\title{
A new clinopyroxene-liquid barometer, and implications for magma storage pressures under Icelandic rift zones
}

DOI:

10.2138/am-2017-5968

\section{Document Version}

Accepted author manuscript

Link to publication record in Manchester Research Explorer

\section{Citation for published version (APA):}

Neave, D. A., \& Putirka, K. D. (2017). A new clinopyroxene-liquid barometer, and implications for magma storage pressures under Icelandic rift zones. American Mineralogist, 102(4), 777-794. https://doi.org/10.2138/am-20175968

\section{Published in:}

American Mineralogist

\section{Citing this paper}

Please note that where the full-text provided on Manchester Research Explorer is the Author Accepted Manuscript or Proof version this may differ from the final Published version. If citing, it is advised that you check and use the publisher's definitive version.

\section{General rights}

Copyright and moral rights for the publications made accessible in the Research Explorer are retained by the authors and/or other copyright owners and it is a condition of accessing publications that users recognise and abide by the legal requirements associated with these rights.

\section{Takedown policy}

If you believe that this document breaches copyright please refer to the University of Manchester's Takedown Procedures [http://man.ac.uk/04Y6Bo] or contact uml.scholarlycommunications@manchester.ac.uk providing relevant details, so we can investigate your claim.

\section{OPEN ACCESS}


Revision 2

\section{A New Clinopyroxene-liquid Barometer, and Implications for Magma}

\section{Storage Pressures under Icelandic Rift Zones}

4

$7 \quad{ }^{1}$ Leibniz Universität Hannover, Institut für Mineralogie, Callinstraße 3, 30167 Hannover, Germany

$8 \quad{ }^{2}$ Department of Earth and Environmental Sciences, California State University-Fresno, 2345 East San Ramon Avenue, MS/MH24, Fresno, California 93720, U.S.A.

11 *Corresponding author: Leibniz Universität Hannover, Institut für Mineralogie, Callinstraße 3, 30167 Hannover, Germany Phone: +49 (0) 511 762-3222, Fax: +49 (0) $511762-3045$ Email: d.neave@mineralogie.uni-hannover.de

15

16 Revised manuscript for resubmission to American Mineralogist

17

18 November 2016

19

20 Number of words (main text only): 7694

21

d.neave@mineralogie.uni-hannover.de 
26 Pressure is one of the key variables that controls magmatic phase equilibria. However, estimating magma

27 storage pressures from erupted products can be challenging. Various barometers have been developed

28 over the past two decades that exploit the pressure-sensitive incorporation of jadeite (Jd) into

29 clinopyroxene. These Jd-in-clinopyroxene barometers have been applied to rift zone magmas from

30 Iceland, where published estimates of magma storage depths span the full thickness of the crust, and

31 extend into the mantle. Tests performed on commonly used clinopyroxene-liquid barometers with data

32 from experiments on $\mathrm{H}_{2} \mathrm{O}$-poor tholeiites in the $1 \mathrm{~atm}$ to $10 \mathrm{kbar}$ range reveal substantial pressure-

33 dependent inaccuracies, with some models overestimating pressures of experimental products equilibrated

34 at $1 \mathrm{~atm}$ by up to $3 \mathrm{kbar}$. The pressures of closed-capsule experiments in the $1-5 \mathrm{kbar}$ range are also

35 overestimated, and such errors cannot be attributed to $\mathrm{Na}$ loss, as is the case in open furnace experiments.

36 The following barometer was calibrated from experimental data in the 1 atm to $20 \mathrm{kbar}$ range to improve

37 the accuracy of Jd-in-clinopyroxene barometry at pressures relevant to magma storage in the crust:

$$
\mathrm{P}(\mathrm{kbar})=-26.27+39.16 \frac{\mathrm{T}(\mathrm{K})}{10^{4}} \ln \left[\frac{\mathrm{X}_{\mathrm{Jd}}^{\mathrm{cpx}}}{\mathrm{X}_{\mathrm{NaO}_{0.5}}^{\mathrm{liq}} \mathrm{X}_{\mathrm{AlO}_{1.5}}^{\mathrm{liq}}\left(\mathrm{X}_{\mathrm{SiO}_{2}}^{\mathrm{liq}}\right)^{2}}\right]-4.22 \ln \left(\mathrm{X}_{\mathrm{DiHd}}^{\mathrm{cpx}}\right)+78.43 \mathrm{X}_{\mathrm{AlO}_{1.5}}^{\mathrm{liq}}+393.81\left(\mathrm{X}_{\mathrm{NaO}_{0.5}}^{\mathrm{liq}} \mathrm{X}_{\mathrm{KO}_{0.5}}^{\mathrm{liq}}\right)^{2}
$$

38 This new barometer accurately reproduces its calibration data with a standard error of estimate (SEE) of

$39 \pm 1.4 \mathrm{kbar}$, and is suitable for use on hydrous and anhydrous samples that are ultramafic to intermediate in

40 composition, though should be used with caution below $1100{ }^{\circ} \mathrm{C}$ and at oxygen fugacities greater than one

$41 \log$ unit above the QFM buffer. Tests performed using with data from experiments on $\mathrm{H}_{2} \mathrm{O}$-poor tholeiites

42 revealed that $1 \mathrm{~atm}$ runs were overestimated by less than the model precision (1.2 kbar); the new

43 calibration is significantly more accurate than previous formulations. Many current estimates of magma

44 storage pressures may therefore need to be reassessed. To this end, the new barometer was applied to

45 numerous published clinopyroxene analyses from Icelandic rift zone tholeiites that were filtered to

46 exclude compositions affected by poor analytical precision or collected from disequilibrium sector zones.

47 Pressures and temperatures were then calculated using the new barometer in concert with equation 33

48 from Putirka (2008). Putative equilibrium liquids were selected from a large database of Icelandic glass 
49 and whole-rock compositions using an iterative scheme because most clinopyroxene analyses were too

50 primitive to be in equilibrium with their host glasses. High-Mg\# clinopyroxenes from the highly primitive

51 Borgarhraun eruption in north Iceland record a mean pressure in the lower crust (4.8 kbar). All other

52 eruptions considered record mean pressures in the mid-crust, with primitive clinopyroxene populations

53 recording slightly higher pressures $(3.5-3.7 \mathrm{kbar})$ than evolved populations $(2.5-2.8 \mathrm{kbar})$. Thus, while

54 some magma processing takes place in the shallow crust immediately beneath Iceland's central volcanoes,

55 magma evolution under the island's neovolcanic rift zones is dominated by mid-crustal processes.

57 Key words: thermobarometry; clinopyroxene-liquid equilibria; Iceland; magma plumbing

\section{INTRODUCTION}

\section{Clinopyroxene-liquid Barometry-Background and Applications}

61 Alongside composition, crystallinity, temperature and oxygen fugacity, pressure is one of the primary

62 intensive variables that controls magmatic phase equilibria (Yoder and Tilley 1962; Blundy and Cashman

63 2008). This raises the possibility of estimating magma storage pressures using observed phase equilibria

64 relations and information from other intensive variables. Indeed, determining magma storage pressures,

65 and hence depths, is essential for various reasons. For example, understanding the distribution of magma

66 storage depths within the lithosphere provides information about crustal formation mechanisms in both

67 oceanic and continental settings (Henstock et al. 1993; Kelemen et al. 1997; Annen et al. 2006).

68 Estimating pre-eruptive magma storage depths is also essential for integrating petrological records of

69 magmatism with expressions of ongoing unrest such as seismicity, ground deformation and gas emission

70 in volcanically active regions (Edmonds 2008; Sigmundsson et al. 2010; Tarasewicz et al. 2014). With the

71 aim of improving the accuracy with which magma storage pressures can be estimated, we assessed the

72 performance of various published clinopyroxene-liquid barometers. To anticipate our results, we find that

73 some barometers overestimate reported experimental pressures at $<7$ kbar. We thus develop a new jadeite-

74 in-clinopyroxene barometer optimized for use at crustal pressures on hydrous and anhydrous 
compositions. We then recalculate storage pressures for a series of Icelandic rift tholeiites from which

76 diverse clinopyroxene-liquid pressures have been reported in recent years.

78 The number of barometric tools available for estimating magma storage pressures has grown considerably

79 over the past 25 years. Current barometric methods range from exploiting volatile solubility laws (e.g.,

80 Newman and Lowenstern 2002; Moore 2008) or equations of state (Hansteen and Klügel 2008) to

81 determine melt and fluid inclusion entrapment pressures, through to calibrating pressure-sensitive phase

82 equilibria relations using experimental data (e.g., Putirka 2008). However, these various barometric

83 methods are subject to numerous assumptions and unavoidably return pressure estimates with

84 considerable uncertainties. For example, while the solubilities of $\mathrm{H}_{2} \mathrm{O}$ and $\mathrm{CO}_{2}$ in silicate melts are

85 generally well understood (Dixon and Stolper 1995; Lesne et al. 2011; Shishkina et al. 2014), many recent

86 studies have demonstrated that interpreting melt inclusion entrapment pressures can be complicated by

87 post-entrapment processes such as diffusive reequilibration, shrinkage bubble formation and the

88 precipitation of solid carbon phases (Bucholz et al. 2013; Hartley et al. 2014; Moore et al. 2015; Wallace

89 et al. 2015). Although condensed phase barometry (i.e., barometry based on solid-solid or solid-liquid

90 phase equilibria) can avoid the challenges presented by melt and fluid inclusions, it is fundamentally

91 limited in other ways. For example, determining magma storage pressures is complicated not only by the

92 mostly small volume contrasts associated with most mineral-mineral or mineral-liquid equilibria, but also

93 by the small number of phases present in many magmas (e.g., melt + olivine \pm plagioclase \pm

94 clinopyroxene in the case of many mafic magmas; Grove et al. 1992), which limits the number of

95 reactions available for barometric use.

96

97 Fortunately for igneous petrologists, the incorporation of jadeite $\left(\mathrm{NaAlSi}_{2} \mathrm{O}_{6} ; \mathrm{Jd}\right)$ into clinopyroxene is

98 strongly pressure dependent, with high Jd contents stabilized at high pressures as a result of the large

99 partial molar volume change associated with the formation of the Jd component (Putirka et al. 1996;

100 Holland and Powell 1998; Putirka 2016). About twenty years ago, Putirka et al. (1996) presented a series 
101 of equations describing the pressure-dependent Jd-liquid (liq) reaction, as well as the strongly 102 temperature-dependent Jd into diopside-hedenbergite $\left(\mathrm{Ca}(\mathrm{Mg}, \mathrm{Fe}) \mathrm{Si}_{2} \mathrm{O}_{6}\right.$; DiHd) and calcium Tschermak's 103 component $\left(\mathrm{CaAlAlSiO}_{6}\right.$; CaTs) into DiHd exchange reactions. These thermobarometric equations were 104 subsequently reformulated in 2003 to extend their applicability to felsic and hydrous systems(Putirka et 105 al. 2003), before being reviewed further five years later (Putirka 2008).

107 Perhaps unsurprisingly, these clinopyroxene-liquid thermobarometers have now seen extensive use for 108 some years. A far from exhaustive list of barometric studies that have used clinopyroxene-liquid equilibria 109 would include the description of deep, multi-level magmatic differentiation under the Canary Islands 110 (Hansteen et al. 1998; Klügel et al. 2005; Stroncik et al. 2009), as well as the identification and 111 subsequent re-evaluation of deep fractionation recoded by high-Al clinopyroxene crystals in alkaline 112 magmas from Haleakala, Hawaii (Chatterjee et al. 2005; Hammer et al. 2016). Clinopyroxene-liquid 113 equilibria have also been used to define trans-crustal magma plumbing systems under Mt. Etna amongst 114 other locations (Giacomoni et al. 2016). To improve the suitability of clinopyroxene-liquid 115 thermobarometers for studying evolved alkaline systems, a series of recalibrated thermobarometric 116 expressions have been developed and applied to Mt. Vesuvius and Campi Flegrei in Italy (Masotta et al. 117 2013), as well as to Nemrut in Turkey (Macdonald et al. 2015).

119 Clinopyroxene-liquid thermobarometers have also been applied to the products of several Icelandic 120 eruptions. For example, clinopyroxene-liquid storage pressure from the primitive Borgarhraun lava in the 121 on-axis Northern Volcanic Zone (NVZ) of Northern Iceland indicate that clinopyroxene crystallization 122 occurred close to the Moho (>20 km; Maclennan et al. 2003a; Winpenny and Maclennan 2011). These 123 high storage pressures are also consistent with phase equilibria experiments and estimates from olivine124 plagioclase-augite-melt (OPAM) boundary barometry (Yang et al. 1996; Maclennan et al. 2012). In the 125 southern, off-axis extension of Iceland's Eastern Volcanic Zone (sEVZ), a bimodal distribution of storage 126 depths has been inferred for the 2010 Eyjafjallajökull-Fimmvörðuháls eruption, with the basalts erupted 
127 from the flank thought to have been sourced from substantially greater depths $(16-18 \mathrm{~km})$ than the 128 benmoreites erupted from the summit (2-5 km; Keiding and Sigmarsson 2012). Similar vertically 129 extensive magma plumbing systems have also been inferred from the products of the neighboring Katla 130 volcanic system (Budd et al. 2016).

132 The importance of mid-crustal storage has also been demonstrated in the products of the 1783-1784 Laki 133 and 10 ka Grímsvötn tephra series eruptions from the on-axis portion of the Eastern Volcanic Zone (EVZ;

134 Neave et al. 2013, 2015). However, these studies of the EVZ proper used substantially different 135 approaches from those used in studies of the sEVZ. Firstly, instead of using the carrier melt as the 136 equilibrium liquid for thermobarometric calculations, putative equilibrium liquids were selected from a 137 large database of Icelandic glass and whole-rock analyses on the basis of being in Fe-Mg, Ti and CaTs 138 component equilibrium with measured clinopyroxenes (e.g., Winpenny and Maclennan 2011). In other 139 words, no a priori assumptions about which liquids would be in equilibrium with clinopyroxene crystals 140 were made. Avoiding such assumptions was deemed to be essential because of the extensive 141 disequilibrium within and between the different components of Icelandic magmas (Halldórsson et al. 142 2008; Maclennan 2008; Neave et al. 2014). For example, even though Keiding and Sigmarsson (2012) 143 and Budd et al. (2016) performed thermobarometric calculations on clinopyroxene compositions in Fe$144 \mathrm{Mg}$ equilibrium with co-erupted glass or whole-rock compositions, only the outermost rims of analyzed 145 crystals may have been co-genetic with the melts that carried them to the surface; magma mixing could 146 have decoupled earlier growth phases of such crystals from their equilibrium melts. Besides, even if a 147 system establishes $\mathrm{Fe}-\mathrm{Mg}$ exchange equilibrium, the equilibration of pressure-dependent $\mathrm{NaAl}-\mathrm{CaMg}$ 148 exchange is by no means guaranteed; different components may equilibrate at different rates. Filtering for 149 Fe-Mg equilibrium alone may thus be an insufficient test for equilibrium in systems where mixing is 150 prevalent (Zellmer et al. 2014). Moreover, Fe-Mg exchange is insensitive to the disequilibrium growth of 151 clinopyroxene, and testing for equilibrium across multiple clinopyroxene components is probably more 152 robust (Mollo et al. 2013a). Secondly, the accuracy of the barometric equations used in the EVZ studies 
153 was tested by applying them to experiments on mafic compositions in the 1-7 kbar range. The pressures

154 from experimental clinopyroxene-liquid pairs were generally found to exceed the pressures at which 155 experiments were carried out, so empirical corrections were applied to the results of calculations 156 performed in clinopyroxene from the Laki and $10 \mathrm{ka}$ Grímsvötn tephra series eruptions (Neave et al. $1572013,2015)$.

159 The magnitudes of empirical corrections proposed by Neave et al. $(2013,2015)(-1.5$ and -2.7 kbar 160 respectively at a true pressure of $3 \mathrm{kbar}$ ) are comparable with the $2-3$ kbar overestimation of most $1 \mathrm{~atm}$ 161 experimental data noted by Putirka (2008) when testing various Jd-in-clinopyroxene barometers (Putirka 162 et al. 1996, 2003). This overestimation was initially attributed to $\mathrm{Na}$ loss during open furnace experiments 163 artificially shifting the equilibrium constant of Jd formation in favor of higher pressure estimates (Tormey 164 et al. 1987; Putirka 2008). However, the persistence of this overestimation when barometers are applied to 165 the products of higher pressure experiments carried out in closed capsules suggests that Na volatilization 166 alone cannot account for the poor accuracy of Jd-in-clinopyroxene barometers at low pressures. 167 Unfortunately, the tests carried out by Neave et al. $(2013,2015)$ are insufficient to evaluate the 168 performance of currently available barometers robustly: they were performed using an incomplete 169 experimental database that was not filtered for the attainment of clinopyroxene-liquid equilibrium. To 170 provide more reliable evaluation of published barometers, we therefore carried out a series of tests on a 171 much larger experimental database.

\section{Evaluating the Performance of Published Clinopyroxene-liquid Barometers}

174 When the first Jd-in-clinopyroxene barometer was proposed by Putirka et al. (1996), few high175 temperature phase equilibria data were available for mafic systems above $1 \mathrm{~atm}$ and below 7 kbar176 arguably, the pressure interval where most magma reservoirs are located (e.g., Singh et al. 2006; Cashman

177 and Sparks 2013; Tarasewicz et al. 2014; Gudmundsson et al. 2016) -because of the experimental 178 challenges of working under these conditions. Many 1 atm experiments carried out before the mid-1990s 
179 also experienced $\mathrm{Na}$ loss, limiting their use in calibrating Jd exchange equilibria (Tormey et al. 1987).

180 However, a range of technological developments over the past few decades have greatly expanded the

181 number of low- to moderate-pressure ( $\leq 7 \mathrm{kbar})$ experiments available for calibrating and testing

182 thermobarometers. Notable advancements include: introducing procedures for minimizing Na loss during

183 open furnace experiments (Tormey et al. 1987; Yang et al. 1996); developing rapid quench devices for

184 internally heated pressure vessels (IHPVs; Berndt et al. 2002; Holloway et al. 1992; Moore and

185 Carmichael 1998); and modifying piston cylinder assemblies to achieve reproducible pressures when

186 operating below 7 kbar (Moore et al. 2008).

188 Phase equilibria experiments from the following sources were thus compiled to evaluate published 189 clinopyroxene-liquid barometers: Berndt et al. (2005), Botcharnikov et al. (2008), Grove et al. (1992),

190 Husen et al. (2016), Thy et al. (2006), Toplis and Carroll (1995), Villiger et al. (2004, 2007), Whitaker et

191 al. (2007, 2008) and Yang et al. (1996). We only include low- $\mathrm{H}_{2} \mathrm{O}\left(\mathrm{H}_{2} \mathrm{O} \leq 1 \mathrm{wt} . \%\right)$ experiments that were

192 carried out at $\leq 10 \mathrm{kbar}$ with an $\mathrm{fO}_{2}$ between the $\mathrm{C}-\mathrm{CO}_{2}-\mathrm{CO}$ buffer (i.e., in equilibrium with graphite 193 capsules) and one log unit above the QFM buffer (QFM+1). These conditions encompass the anticipated 194 magma storage conditions for tholeiitic basalts in oceanic settings (Michael 1995; Cottrell and Kelley 195 2011). They also exclude the oxidizing conditions $\left(\mathrm{fO}_{2}>\mathrm{QFM}+1\right)$ under which the presence of $\mathrm{Fe}^{3+}$ in 196 clinopyroxene can stabilize an aegirine component $\left(\mathrm{NaFe}^{3+} \mathrm{Si}_{2} \mathrm{O}_{6}\right.$; Aeg) that complicates the solution of $197 \mathrm{Na}$ into pyroxene, with an unknown impact on the true Jd fraction, compared to that calculated from 198 major element oxide data (Blundy et al. 1995). Furthermore, only clinopyroxene-liquid pairs with

$199 \quad \mathrm{~K}_{\mathrm{d} \mathrm{Fe}-\mathrm{Mg}}^{\mathrm{cpx}-\mathrm{liq}}$ values within $20 \%$ of equilibrium values calculated using equation 35 from Putirka (2008) were 200 considered. The compiled experimental data are provided in the electronic appendix.

202 The results of our tests on previously published clinopyroxene-liquid barometers are summarized in 203 Figure 1. All barometric calculations were performed using experimental temperatures and quoted $\mathrm{H}_{2} \mathrm{O}$ 
contents where available. Where no $\mathrm{H}_{2} \mathrm{O}$ contents were provided, experiments were assumed to be 205 anhydrous. Calculations using data from Villiger et al. (2004, 2007), as well as data from composition 70206002 of Grove et al. (1992), returned extremely variable pressure estimates and were therefore excluded 207 from regressions performed to evaluate the performance of the barometers. We also excluded the results 208 of calculations from a few 1 atm experiments that returned spurious pressures of less than $-8 \mathrm{kbar}$.

210 Figure 1a shows the performance of model P1 from Putirka et al. (1996), the first formulation of the Jd211 in-clinopyroxene barometer (standard error of estimate $=1.4 \mathrm{kbar}$ ). Although the test dataset can be fitted 212 reasonably well using a simple linear model $\left(r^{2}=0.81\right.$, SEE $\left.=1.1 \mathrm{kbar}\right)$, the regression does not pass 213 through the origin. Specifically, while the estimates for high pressure ( $\geq 7 \mathrm{kbar}$ ) experiments lie within one 214 SEE of experimental values (i.e., within 1.4 kbar), estimates for low-pressure experiments are 215 significantly overestimated (intercept $=3.0 \mathrm{kbar}$ ), resulting in a mean residual between calculated and 216 experimental pressures of $2.3 \mathrm{kbar}$. However, given that this model was only calibrated using $\geq 8 \mathrm{kbar}$ 217 experiments, the poor accuracy at lower pressures is perhaps not surprising.

219 Figure $1 \mathrm{~b}$ shows the performance of equation 30 from Putirka (2008), a recalibrated Jd-in-clinopyroxene 220 barometer (calibration SEE $=1.6$ kbar) designed for use with evolved and hydrous compositions as well 221 as with primitive and nominally anhydrous compositions (cf., Putirka et al. 2003). Despite being 222 calibrated with a larger and more compositionally diverse dataset, this barometer performed similarly to 223 model P1 from Putirka et al. (1996) in our tests: $r^{2}=0.82, \mathrm{SEE}=0.9 \mathrm{kbar}$, intercept $=3.0 \mathrm{kbar}$ and mean 224 residual $=2.1$ kbar. Nevertheless, the low SEE is consistent with the analysis of Putirka (2008) that this is 225 the most precise formulation of the Jd-in-clinopyroxene barometer to date for mafic systems.

227 Figure 1c shows the performance of equation 32a from Putirka (2008), a barometer that, following the 228 approach of Nimis (1995), is based on temperature and clinopyroxene composition alone (calibration SEE $229=3.1 \mathrm{kbar})$. Although the test data are fitted well by a simple linear model $\left(r^{2}=0.89\right.$; SEE $\left.=0.9\right)$, pressure 
230 estimates are consistently $\sim 1-2$ kbar too high, with the magnitude of the overestimation being greatest at

$2311 \mathrm{~atm}$ (intercept $=2.3 \mathrm{kbar}$, mean residual $2.0 \mathrm{kbar}$ ). We therefore suggest that the systematic 232 overestimation of pressure noted by Putirka (2008) when applying this model to hydrous compositions 233 may extend to $\mathrm{H}_{2} \mathrm{O}$-poor compositions at low to moderate pressures $(<10 \mathrm{kbar})$.

235 Figure 1d shows the performance of equation 32c from Putirka (2008), a barometer based on A1 236 partitioning between clinopyroxene and liquid ( $\mathrm{SEE}=1.5 \mathrm{kbar}$ ). This barometer performed worst out of 237 the four barometric expressions tested: $r^{2}=0.70, \mathrm{SEE}=1.5 \mathrm{kbar}$, intercept $=2.6 \mathrm{kbar}$ and mean residual 2381.8 kbar. Despite exploiting Al partitioning instead of Jd formation, this barometer shows a similar 239 pressure-dependent accuracy to the two Jd-in-clinopyroxene barometers shown in Figures 1a and 1b: the 240 barometer is accurate at high pressures ( $\geq 7 \mathrm{kbar})$, but increasingly inaccurate at lower pressures.

242 A crucial observation from Figure 1 is that pressure overestimation is not restricted to experiments carried 243 out at $1 \mathrm{~atm}$ in which $\mathrm{Na}$ loss by volatilization may have occurred. Applying Jd-in-clinopyroxene 244 barometers to data from 1-4 kbar experiments carried out in zirconium-hafnium-molybdenum (ZHM) 245 cold seal, IHPV and piston cylinder equipment also results in values 1.5-3.0 kbar above experimental 246 pressures. Pressure overestimations for these closed-capsule experiments cannot be attributed to Na loss 247 from their coexisting liquids, and the cause of the Jd-in-clinopyroxene barometers' spuriously high 248 pressure estimates at low pressures must lie elsewhere. Encouragingly, though, these existing barometers 249 qualitatively, at least, recover the sense of pressure change in the test dataset: taking the mean calculated 250 pressure of the various isobaric datasets, it is possible to place these isobaric sets in the correct order. This 251 indicates that there is merit to the clinopyroxene-liquid approach to barometry, which might be resolved 252 by a suitable recalibration.

\section{METHOD}

255 The performance of a barometer depends strongly on how calibration data are selected. To calibrate a new 
256 clinopyroxene-liquid barometer that is accurate at crustal pressures, it is thus essential to include low- to 257 moderate-pressure experiments $(\leq 7 \mathrm{kbar})$ in the calibration dataset. Furthermore, given that even small 258 amounts of $\mathrm{H}_{2} \mathrm{O}$ can have a strong effect on mineral-liquid equilibria (e.g., Almeev et al. 2007, 2012; 259 Médard et al. 2008), it is also important to include hydrous experiments. A calibration database was thus 260 compiled from the following sources: Blatter and Carmichael (2001), Kinzler and Grove (1992), Moore 261 and Carmichael (1998), Putirka et al. (1996), Sisson and Grove (1993) and Yang et al. (1996). The 262 calibration database contains a total of 113 experiments saturated in clinopyroxene \pm olivine \pm plagioclase $263 \pm$ orthopyroxene \pm spinel \pm hornblende \pm magnetite \pm ilmenite. The inclusion of 1 atm experiments from

264 Yang et al. (1996) represents a key development from the calibration datasets used in previous barometer 265 calibrations. Importantly, this set of 1 atm experiments experienced negligible Na loss. Further details are 266 summarized in Table 1, and the complete dataset is provided in the electronic appendix.

268 Liquid and clinopyroxene components were calculated following the methods outlined in Tables 1 and 3 269 from Putirka (2008) respectively. All the clinopyroxene compositions in the calibration dataset return six270 oxygen cation sums close to $4(3.97-4.05)$, confirming that they are stoichiometric. Linear regression was 271 performed following the procedures outlined in Putirka et al. (1996) and Putirka (2008) to determine the 272 regression coefficients. Following the qualitative success of prior models (Figure 1), the regression 273 equation is based on a thermodynamic description of $\mathrm{Jd}$ formation, and includes empirical terms to 274 improve the precision of pressure estimates. The new Jd-in-clinopyroxene barometer has the following 275 form:

$276 \quad \mathrm{P}(\mathrm{kbar})=-26.27+39.16 \frac{\mathrm{T}(\mathrm{K})}{10^{4}} \ln \left[\frac{\mathrm{X}_{\mathrm{d}}^{\mathrm{cpx}}}{\mathrm{X}_{\mathrm{NaO}_{0.5}}^{\mathrm{liq}} \mathrm{X}_{\mathrm{AlO}_{1.5}}^{\mathrm{liq}}\left(\mathrm{x}_{\mathrm{SiO}_{2}}\right)^{2}}\right]-4.22 \ln \left(\mathrm{X}_{\mathrm{DiHd}}^{\mathrm{cpx}}\right)+78.43 \mathrm{X}_{\mathrm{AlO}_{1.5}}^{\mathrm{liq}}+393.81\left(\mathrm{X}_{\mathrm{NaO}_{0.5}}^{\mathrm{liq}} \mathrm{X}_{\mathrm{KO}_{0.5}}^{\mathrm{liq}}\right)^{2}$

277 This new barometer is calibrated for ultramafic to intermediate compositions in the $0.001-20$ kbar and $278950-1400{ }^{\circ} \mathrm{C}$ ranges. Although this study is focused primarily on $\mathrm{H}_{2} \mathrm{O}$-poor tholeiites, the inclusion of $279 \mathrm{H}_{2} \mathrm{O}$-rich experiments in the calibration dataset means that the barometer is also suitable for use with 280 hydrous compositions. However, because of Aeg component formation at high $\mathrm{fO}_{2}$ (Blundy et al. 1995), 
281 we advise caution when using this barometer under oxidizing conditions $\left(f \mathrm{O}_{2} \geq \mathrm{QFM}+1\right)$; we do not

282 calculate an $\mathrm{Fe}^{3+}$ or Aeg component, but pressures may be overestimated if $\mathrm{Na}$ is accidentally assigned to

283 Jd when it should be assigned to Aeg. A spreadsheet for calculating pressures is provided in the electronic

284 appendix.

\section{RESULTS}

287 Calibration data are fitted well by a simple model (Figure $2 \mathrm{a} ; r^{2}=0.95$; SEE $=1.3 \mathrm{kbar}$ ). Importantly, the 288 accuracy of the new barometer does not vary systematically as a function of pressure (intercept $=0.3$ 289 kbar); the inaccuracies visible in Figure 1 appear to have been avoided. Given that Jd-in-clinopyroxene 290 barometers depend on temperature as well as composition, they are usually solved iteratively using a 291 complementary thermometric expression, which may itself be pressure dependent. Equation 33 from 292 Putirka (2008) is the most precise clinopyroxene-liquid thermometer currently available (calibration SEE $293=45^{\circ} \mathrm{C}$ ). This thermometer was calibrated using a large global dataset that has minimal overlap with the 294 dataset used to calibrate equation 1. Figure $2 \mathrm{~b}$ shows pressures estimated for the calibration dataset by 295 solving our new Jd-in-clinopyroxene barometer iteratively with equation 33 from Putirka (2008). 296 Encouragingly, iteratively calculated pressures are very similar to those calculated using experimentally 297 reported temperatures; neither the accuracy not the precision of the pressure estimates suffer from being 298 calculated iteratively $\left(r^{2}=0.95 ;\right.$ SEE $=1.4 \mathrm{kbar}$; intercept $\left.=0.6 \mathrm{kbar}\right)$. Corresponding iteratively 299 calculated temperatures are shown in Figure 2c. Although temperatures appear to be calculated more 300 precisely than the thermometer's quoted uncertainty (SEE $=28^{\circ} \mathrm{C}$ versus $45^{\circ} \mathrm{C}$ from Putirka, 2008), they 301 are systematically overestimated below $1100{ }^{\circ} \mathrm{C}$. While equation 33 from Putirka (2008) performs well 302 when paired with our new barometer at the temperatures of interest for this study $\left(1100-1300{ }^{\circ} \mathrm{C}\right)$, we 303 advise caution when using this barometer-thermometer combination at low temperatures $\left(\leq 1100{ }^{\circ} \mathrm{C}\right)$.

305 A direct comparison between pressures calculated with the original Jd-in-clinopyroxene calibration from 306 Putirka et al. (1996) and our new calibration is shown in Figure 2d. While the original model reproduces 
the low pressures of hydrous experiments in the 0.5-2.5 kbar range (Sisson and Grove 1993; Blatter and

308 Carmichael 2001), the $1 \mathrm{~atm}$ experiments of Yang et al. (1996) are overestimated by $\sim 4 \mathrm{kbar}$ and do not

309 lie on a regression through the dataset. Comparing Figure 2a with Figure $2 \mathrm{~d}$ suggests that our new

310 barometer does not suffer from the same inaccuracies at low pressures present in other clinopyroxene-

311 liquid barometers.

\section{DISCUSSION}

\section{Evaluating the Jd-in-clinopyroxene Barometer}

315 Although regression statistics from calibration datasets provide important information about the precision

316 of thermobarometric models, it is important to verify model performance with independent datasets that

317 do not contain calibration data. Figure 3 shows the results of tests carried out using a global dataset of

318 clinopyroxene-liquid pairs from experiments conducted above 1 atm and below $20 \mathrm{kbar}$ to avoid the

319 effects of Na loss in legacy datasets while remaining within the barometer's calibration range. This global

320 dataset does not include the data from experiments on $\mathrm{H}_{2} \mathrm{O}$-poor tholeiites used to produce Figure 1, and

321 is provided in the electronic appendix. Clinopyroxene-liquid pairs were also filtered on the basis of being

322 within $20 \%$ of $\mathrm{K}_{\mathrm{d} \mathrm{Fe}-\mathrm{Mg}}^{\mathrm{cpx}-\mathrm{liq}}$ equilibrium according to equation 35 from Putirka (2008). A total of 624

323 clinopyroxene-liquid pairs fitted these criteria (Bender et al. 1978; Johnston 1986; Kelemen et al. 1990;

324 Meen 1990; Bartels et al. 1991; Vander Auwera and Longhi 1994; Patiño-Douce and Beard 1996; Falloon

325 et al. 1999, 2001, Grove et al. 1997, 2003; Kinzler 1997; Falloon et al. 1997; Gaetani and Grove 1998;

326 Johnson 1998; Kogiso et al. 1998; Robinson et al. 1998; Takahahshi et al. 1998; Vander Auwera et al.

327 1998; Draper and Green 1999; Pickering-Witter and Johnston 2000; Kogiso and Hirschmann 2001;

328 Müntener et al. 2001; Berndt et al. 2001; Schwab and Johnston 2001; Dann et al. 2001; Pichavant et al.

329 2002; Bulatov et al. 2002; Wasylenki et al. 2003; Elkins-Tanton and Grove 2003; Barclay 2004; Laporte

330 et al. 2004; Médard et al. 2004; Parman and Grove 2004; Kägi et al. 2005; Scoates et al. 2006; Di Carlo et

331 al. 2006; Ganino et al. 2013). 
333 Figure 3a shows pressures calculated for the global dataset using imposed experimental temperatures.

334 Although simple linear fits to the global dataset are worse than similar fits to the calibration dataset $\left(r^{2}=\right.$ $3350.51 ; \mathrm{SEE}=3.8 \mathrm{kbar}$; intercept $=1.5 \mathrm{kbar})$, the mean residual between experimental and calculated 336 pressures is slightly smaller $(-1.3$ kbar). Barometer performance was marginally improved when 337 pressures were calculated iteratively (Figure $3 \mathrm{~b} ; r^{2}=0.58, \mathrm{SEE}=3.6 \mathrm{kbar}$; intercept $=0.8 \mathrm{kbar}$; mean 338 residual $=-1.3 \mathrm{kbar}$ ). The performance of our new barometer is nonetheless comparable with the 339 performance of previous barometers subjected to testing against global datasets (Putirka 2008). However, 340 the usefulness of performing global tests is somewhat unclear given that many of the experiments in the 341 global dataset were performed on compositions either beyond the range of barometer calibration or of 342 little relevance to the investigation of magmatic processes in the crust. For example, low-pressure (2-4 343 kbar), high- $\mathrm{fO}_{2}$ (NNO to $\mathrm{NNO}+2.3$ ) experiments on phonolitic compositions return pressures $\sim 10 \mathrm{kbar}$

344 higher than experimental pressures (Figure 3; Berndt et al. 2001). This discrepancy is perhaps 345 unsurprising given that there are no highly alkaline or highly oxidized compositions in the calibration 346 dataset, and may serve as an example of how pressures may be overestimated when Na partitions as Aeg 347 rather than $\mathrm{Jd}$. We therefore carried out a more specific evaluation of barometer performance in basaltic 348 systems using the tholeiitic test dataset used to produce Figure 1. The experiments of Yang et al. (1996) 349 were, however, excluded because they were used in the barometer calibration. Calculations performed on 350 data from Villiger et al. (2004, 2007) and composition 70-002 from Grove et al. (1992) were also 351 excluded because of the large pressure ranges estimated for these experiments.

353 Figure 4a shows pressures calculated for test data with imposed experimental temperatures and Figure 4b 354 shows pressures for the same data calculated iteratively using equation 33 from Putirka (2008). Figure 4c 355 shows the iteratively calculated temperatures corresponding to Figure $4 \mathrm{~b}$. Pressure estimates for the test 356 dataset were determined with similar precisions using both imposed and iteratively calculated 357 temperatures (SEE $=1.1$ and $1.2 \mathrm{kbar}$ respectively). Encouragingly, the mean residuals between 
experimental and calculated pressures are also small ( 0.6 and 0.8 kbar respectively). The barometer's ability to reproduce the calibration dataset $(\mathrm{SEE}=1.4 \mathrm{kbar}$; Figure $2 \mathrm{~b})$ is a conservative and thus more

360 appropriate estimate of barometer precision for tholeiitic systems.

362 Regressions through pressures from the test dataset do not pass through the origin as closely as 363 regressions through pressures from the calibration dataset do: intercepts $=1.1$ and $1.2 \mathrm{kbar}$ when using 364 imposed and iteratively calculated temperatures respectively. The significance of this inaccuracy is 365 unclear. While the specter of $\mathrm{Na}$ loss could still haunt the $1 \mathrm{~atm}$ data used here (Toplis and Carroll 1995;

366 Thy et al. 2006), it is important to note that the magnitude of pressure overestimation at 1 atm is 367 indistinguishable from the barometer's inherent uncertainty. This contrasts with the inaccuracies 368 identified in Figure 1, where the pressures of 1 atm experiments are overestimated by more than 2 SEE 369 ( $\sim 3$ kbar). Indeed, our new barometer returns systematically lower pressures for the test dataset than 370 model P1 from Putirka et al. (1996) (Figure 4d). However, improving the precision and accuracy of 371 thermobarometric expressions of the type we present here is challenging for two reasons. Firstly, both the 372 calibration and application of Jd-in-clinopyroxene barometers are strongly affected by the ability to 373 measure $\mathrm{Na}_{2} \mathrm{O}$ in glasses and clinopyroxenes by electron probe precisely: $\mathrm{Na}_{2} \mathrm{O}$ can be mobile under 374 electron beams and is often present at only $0.1-0.5 \mathrm{wt} . \%$ levels in clinopyroxenes. Secondly, barometry 375 using condensed phases (i.e., solids and liquids) is limited by the small absolute magnitudes of partial 376 molar volume changes associated with reactions that can be exploited as barometers, i.e., a precision of 3771.4 kbar may be close to the limit of what can be achieved using current approaches (Putirka 2016).

\section{Magma Storage Pressures under Icelandic Rift Zones}

380 Selecting Appropriate Clinopyroxene Analyses. Magma storage pressures have been estimated using 381 the products of a number of tholeiitic eruptions from Iceland's neovolcanic rift zones using Jd-in382 clinopyroxene barometry (Maclennan et al. 2001; Winpenny and Maclennan 2011; Hartley and 383 Thordarson 2013; Neave et al. 2013, 2015; Geiger et al. 2016). However, most studies followed different 
methodologies, making inter-eruption comparisons unreliable. For example, different studies used different barometers and different methods of selecting equilibrium clinopyroxene-liquid pairs, and while some studies applied empirical corrections to account for the systematic errors highlighted in Figure 1,

387 others did not. In order to investigate magma storage pressures of Icelandic tholeiites systematically, we 388 compiled clinopyroxene data from the highly primitive Borgarhraun lava $\left(\mathrm{Mg} \#_{\text {liq }} \sim 69\right.$, assuming $\mathrm{Fe}^{3+} / \Sigma \mathrm{Fe}$ $389=0.85$, Shorttle et al. 2015), the moderately primitive Thjórsá and Skuggafjöll flows (Mg\# $\left.\#_{\text {liq }} \sim 50-54\right)$ and 390 the evolved Laki flow and $10 \mathrm{ka}$ Grímsvötn tephra series $\left(\mathrm{Mg} \#_{\text {liq }} \sim 45\right)$. We also included data from the 391 moderately primitive Holuhraun 1 and 2 eruptions $\left(\mathrm{Mg \#}_{\text {liq }} \sim 50\right)$ that took place at the same location as the 392 2014-2015 eruption in 797 and 1862-1864 (Hartley and Thordarson 2013). Data sources are listed in 393 Table 2.

395 Compiled Icelandic clinopyroxene compositions are summarized in Figure 5 using components calculated 396 according to the methods outlined in Table 3 from Putirka (2008). Individual eruptions form distinct 397 arrays in both DiHd-EnFs space and DiHd-CaTs space (Figures 5a and 5b). While some eruptions form 398 single arrays in $\mathrm{Ca} /(\mathrm{Ca}+\mathrm{Mg}+\mathrm{Fe})-\mathrm{Al}$ space, others form multiple arrays (Figure $5 \mathrm{c})$. Eruptions also form 399 single arrays in $\mathrm{Ca} /(\mathrm{Ca}+\mathrm{Mg}+\mathrm{Fe})-\mathrm{Jd}$ space (Figure 5d). The large compositional ranges in Figure 5 400 represent not only the pressure and temperature conditions at which the crystals formed, but also 401 analytical errors, the occurrence of sector zoning and the diversity of primary melt compositions supplied 402 to Icelandic magmatic systems. To calculate storage pressures robustly, the effects of these three factors 403 on barometric calculations must be considered.

405 Analytical errors can strongly affect the results of thermobarometric calculations. We therefore applied 406 two filters to screen our dataset for poor analyses before performing any calculations. Firstly, we excluded 407 all clinopyroxene compositions that returned non-stoichiometric values when cation sums were calculated 408 on a six-oxygen basis (6O). Specifically, analyses with $6 \mathrm{O}$ sums of $<3.99$ or $>4.02$ were discarded. 409 Secondly, we excluded all analyses with $\mathrm{Jd}<0.01$, which represent $\mathrm{Na}_{2} \mathrm{O}$ contents at or below the 
410 detection limit of EPMA. The few analyses with Jd contents below 0.01 lie away from the bulk of the

411 data from their respective eruptions, confirming the poor quality of these analyses.

413 Sector zoning resulting from the variable partitioning of certain elements onto different crystal faces

414 during growth is extremely common in igneous clinopyroxenes (Strong 1969; Nakamura 1973; Downes

415 1974). The rate of crystal growth, itself closely related to the degree of undercooling $(\Delta T)$, exerts a first

416 order control on the style of sector zoning (Kouchi et al. 1983). For example, at high degrees of

417 undercooling $\left(\Delta T \sim-45^{\circ} \mathrm{C}\right)$, pressure-sensitive $\mathrm{Na}$ and $\mathrm{Al}$ partition onto $\{-111\}$ faces of clinopyroxene

418 crystal that record compositions strongly out of equilibrium (Welsch et al. 2016). In contrast, at low

419 degrees of undercooling $\left(\Delta T \sim-20^{\circ} \mathrm{C}\right)$, the sense of partitioning can be reversed, with $\mathrm{Al}$ partitioning

420 variably onto $\{100\},\{010\}$ and $\{110\}$ faces depending on the exact conditions experienced.

421 Clinopyroxenes from tholeiitic systems often display strong sector zoning in their $\mathrm{Ca} /(\mathrm{Ca}+\mathrm{Mg}+\mathrm{Fe})$

422 contents, which results from the disequilibrium partitioning of $\mathrm{Mg}$ and $\mathrm{Fe}$ onto $\{100\}$ faces causing

423 concurrent dilutions of $\mathrm{Ca}$ and $\mathrm{Al}$ (Nakamura 1973). Before performing thermobarometric calculations it

424 is thus essential to evaluate which sector zones were closest to being in equilibrium at the time of 425 crystallization (Hammer et al. 2016). For example, low-Al zones in high-Al clinopyroxenes from the 426 Haleakala ankaramite, Hawai'i, which crystallized at high degrees of undercooling, record the 427 compositions closest to being in equilibrium at the time of formation (Hammer et al. 2016; Welsch et al. 428 2016).

430 In the Icelandic clinopyroxene populations where it is present, sector zoning is clearly resolved in $431 \mathrm{Ca} /(\mathrm{Ca}+\mathrm{Mg}+\mathrm{Fe})-\mathrm{Al}$ space (Figure $5 \mathrm{c})$ : one set of sectors defines a high-Al field with high$432 \mathrm{Ca} /(\mathrm{Ca}+\mathrm{Mg}+\mathrm{Fe})$ while the other defines a low-Al field with variable- $\mathrm{Ca} /(\mathrm{Ca}+\mathrm{Mg}+\mathrm{Fe})$. This type of sector 433 zoning is common in clinopyroxenes formed at low degrees of undercooling in tholeiitic magmas 434 (Nakamura 1973). Following Nakamura (1973), we conclude that the low-Al sectors experienced Ca and 435 Al dilution during growth as a result of the disequilibrium incorporation of $\mathrm{Mg}$ and $\mathrm{Fe}$, and that the high- 
436 Al sectors preserve the compositions that were closest to equilibrium during their near-isothermal 437 crystallization (Neave et al. 2013). We therefore applied a third filter to our clinopyroxene dataset before 438 carrying out thermobarometry: all compositions with $\mathrm{Al}(6 \mathrm{O})<0.11$ were excluded (Figure 5c).

439 Furthermore, almost all un-zoned clinopyroxenes from a series of recent equilibrium crystallization 440 experiments carried out on tholeiitic starting compositions at a range of pressures (1-7 kbar) have Al $441(6 \mathrm{O})>0.11$ (Husen et al. 2016), confirming that high-Al zones preserve the best record of clinopyroxene-

442 liquid equilibrium at the time of crystallization in the samples considered here. It is nonetheless important 443 to note that diffusive pile-up during crystallization at high degrees of undercooling can result in $\mathrm{Al}, \mathrm{Na}$ 444 and Ti enrichments that compromise the identification of near-equilibrium zones (Mollo et al. 2013b).

446 Performing Thermobarometric Calculations. The selection of appropriate equilibrium liquids is a pre447 eminent consideration when calculating storage pressures by Jd-in-clinopyroxene barometry. In some 448 cases, textural relationships between crystals and their carrier liquids (i.e., matrix glasses) indicate that 449 these two phases were in equilibrium at the time of quenching and can be used for thermobarometric 450 calculations. However, many clinopyroxenes are concentrically zoned, reflecting growth in different 451 magmatic environments because of magma mixing and fractionation crystallization prior to eruption. 452 Indeed, many instances of crystal-liquid disequilibrium have been described in Icelandic tholeiites (e.g., 453 Hansen and Grönvold 2000; Halldórsson et al. 2008; Thomson and Maclennan 2013; Neave et al. 2014), 454 demonstrating that equilibrium clinopyroxene-liquid pairs must be selected with care.

456 Kernel density estimates (KDEs) of $\mathrm{Mg} \#_{\mathrm{cpx}}$ values calculated with a bandwidth corresponding to the $1 \sigma$ 457 precision of $\mathrm{Mg} \#_{\mathrm{cpx}}$ determination $( \pm 0.5 \mathrm{~mol} . \%)$ are shown in Figure 6a (Rudge 2008; Thomson and 458 Maclennan 2013). The compositions of clinopyroxene crystals predicted to be in equilibrium with the 459 average carrier liquid compositions from each eruption are shown as vertical bars in Figure 6a. These 460 compositions were calculated using $\mathrm{K}_{\mathrm{d} \text { Fe-Mg }}^{\mathrm{cpx}-\mathrm{Miq}}$ values from equation 35 from Putirka (2008), liquid 
$461 \mathrm{Fe}^{3+} / \Sigma \mathrm{Fe}$ values of 0.85 , temperatures from equation 15 from Putirka (2008) and matrix glass 462 compositions collated from the following sources: Holuhraun 1 and 2, Hartley and Thordarson (2013); 463 Laki, Hartley et al. (2014); 10 ka Grímsvötn tephra series, Neave et al. (2015), Skuggafjöll, Neave et al. 464 (2014); and Borgarhraun Sigurdsson et al. (2000). No matrix glasses are known from the crystalline 465 Thjórsá lava, so the average composition of groundmass separates, which may have experienced olivine 466 and clinopyroxene accumulation, was used instead (Halldórsson et al. 2008). Hence, the equilibrium $467 \mathrm{Mg \#}_{\mathrm{cpx}}$ value calculated for the Thjórsá carrier liquid was probably overestimated. Figure 6a reveals that 468 the majority of clinopyroxene compositions in our compilation crystallized from liquids significantly 469 more primitive than those which carried them to the surface, mirroring similar observations from olivine 470 and plagioclase populations (Hansen and Grönvold 2000; Thomson and Maclennan 2013). Therefore, 471 matrix glass compositions are not plausible equilibrium liquids for most of the analyses in our 472 compilation of Icelandic clinopyroxenes.

474 In order to increase the number of available clinopyroxene-liquid pairs and hence estimate the storage 475 pressures of primitive clinopyroxenes, we used an iterative equilibrium liquid-matching algorithm similar 476 to those used by Winpenny and Maclennan (2011) and Neave et al. (2013, 2015). Putative equilibrium 477 liquids were selected from a large database of Icelandic whole-rock and matrix glass compositions 478 collated by Shorttle and Maclennan (2011), to which further additions have been made from more recent 479 studies (Jude-Eton et al. 2012; Koornneef et al. 2012; Hartley and Thordarson 2013; Hartley et al. 2014; 480 Neave et al. 2014, 2015; Streeter and Dugmore 2014). To avoid selecting geologically implausible alkali 481 basalt compositions, all data from flank zone eruptions were excluded. Furthermore, highly primitive 482 compositions $(\mathrm{MgO}>12 \mathrm{wt} . \%)$ liable to be affected by olivine accumulation were also excluded from the 483 database.

484

485 In the first iteration of the liquid-matching algorithm, equilibrium melts were selected on the basis of 486 being within $20 \%$ of Fe-Mg equilibrium with each clinopyroxene analysis according to the temperature- 
487 independent model of Wood and Blundy (1997). Initial guesses for equilibrium pressures and 488 temperatures were then calculated for every successfully matched clinopyroxene-liquid pair by iteratively 489 solving our new Jd-in-clinopyroxene barometer with equation 33 from Putirka (2008). Pressures and 490 temperatures were subsequently refined by performing several further iterations of this procedure with 491 more stringent criteria for selecting equilibrium melts (cf., Mollo et al. 2013a). Specifically, 492 clinopyroxene-liquid pairs were selected on the basis of being within $10 \%$ of Fe-Mg, DiHd component, 493 CaTs component and Ti equilibrium according to equation 35 from Putirka (2008), the DiHd and CaTs 494 equilibrium models from Putirka (1999) and the Ti partitioning model from Hill et al. (2011) respectively.

495 The inclusion of criteria for Ti and CaTs component equilibrium is important to account for the effects of 496 mantle-derived variability in liquid compositions (Shorttle and Maclennan 2011). Median pressures and 497 temperatures for each clinopyroxene analysis were calculated at the end of each iteration for use as 498 starting guesses in the next iteration.

Interpreting the Results of Thermobarometric Calculations. Out of the initial compilation of 1037 clinopyroxene analyses, a total of 603 were successfully matched to between 1 and 1167 glass and wholerock compositions (median $=184$ matches). $\mathrm{Mg} \#_{\mathrm{cpx}}$ values to which equilibrium liquids were successfully matched are summarized in Figure 6b. Although sufficient matches were made to estimate magma storage pressures for each eruption, no matches were found for some ranges of clinopyroxene composition. For example, no matches were found for the most primitive clinopyroxene analyses from the Borgarhraun lava. In the cases of the Laki and Thjórsá lavas, and the 10 ka Grímsvötn tephra series, matched Mg\# ${ }_{\mathrm{cpx}}$

507 values have bimodal distributions. Given that this bimodality represents the crystallization of different 508 crystal populations under different conditions (Halldórsson et al. 2008; Neave et al. 2013, 2015), storage 509 pressure estimates for the evolved and primitive populations were considered independently. The 510 compositions of successfully matched clinopyroxene analyses are summarized in Figure 7 and form much 511 tighter clusters than the input data shown in Figure 5. 
513 Iteratively calculated pressures and temperatures are summarized in Figure 8 and provided in the 514 electronic appendix. The full dataset of clinopyroxene-liquid pairs is available from the corresponding 515 author on request. As expected, there is an appreciable positive correlation between $\mathrm{Mg} \#_{\mathrm{cpx}}$ and 516 equilibrium temperature $\left(r^{2}=0.64\right.$; Figure $\left.8 \mathrm{a}\right)$. There is no strong relationship between $\mathrm{Mg} \#_{\text {cpx }}$ and 517 equilibrium pressure, with the exception of high-Mg\# clinopyroxenes from the Borgarhraun lava 518 returning higher pressures $\left(r^{2}=0.29\right.$ with Borgarhraun, but 0.13 without; Figure $\left.8 b\right)$. Conversely, while 519 there is probably no relationship between clinopyroxene $\mathrm{Al}(6 \mathrm{O})$ and temperature $\left(r^{2}=0.14\right.$; Figure $\left.8 \mathrm{c}\right)$, 520 there may be a very weak positive correlation between $\mathrm{Al}(6 \mathrm{O})$ and pressure $\left(r^{2}=0.2\right.$; Figure $\left.8 \mathrm{~d}\right)$.

522 In some cases, large ranges of pressures calculated for individual clinopyroxene populations have been 523 interpreted as evidence for vertically extensive magma storage regions (e.g., Budd et al. 2016; Giacomoni 524 et al. 2016). However, the certainty with which pressures can be calculated using clinopyroxene-liquid 525 barometers is limited (Figures 1-4). For example, the new Jd-in-clinopyroxene calibration presented here 526 has an SEE of $1.4 \mathrm{kbar}$, indicating that only $67 \%$ of the calibration data lie within 1.4 kbar of a regression 527 through the calibration dataset. In order to test whether the large pressure ranges observed in Figure 8 528 represent polybaric storage or merely the inherent uncertainty of the barometric calculations, data were 529 converted to KDEs that were in turn fitted with Gaussian functions (Figure 9; Rudge 2008). KDEs were 530 calculated with an imposed bandwidth of $1.4 \mathrm{kbar}$, which is equivalent to the estimated SEE of the 531 barometer calibration. Gaussian functions fitted to pressure KDEs calculated for each clinopyroxene 532 population identified in Figure $6 \mathrm{~b}$ have standard deviations of 1.5-1.8 kbar that are only slightly larger 533 than the SEE of the barometer itself (Table 3). The SEEs of pressures calculated for each clinopyroxene 534 population, which may be better estimates of precision than standard deviations in such datasets (e.g., 535 Putirka 2016), are also substantially smaller than the SEE of the barometer (0.1-0.4 kbar versus 1.4 kbar; 536 Table 3). Thus, the variability in the pressures calculated for individual clinopyroxene populations 537 feasibly reflects uncertainties in either the barometric model or the equilibrium liquid-matching procedure 538 rather than crystallization over a large pressure range. In other words, while different clinopyroxene 
populations may have crystallized at different pressures, individual populations are likely to have crystallized within a narrow pressure window of $0.1-0.4$ kbar.

542 The means of Gaussian fits to the results of thermobarometric calculations represent our best magma

543 storage pressure estimates (Table 3). The highest storage pressures were calculated for the highly

544 primitive $\left(\mathrm{Mg} \#_{\mathrm{cpx}}>85\right)$ Borgarhraun lava $(4.8 \pm 1.8(1 \sigma) \mathrm{kbar})$. However, these values are significantly

545 lower than previous estimates $(8.1 \pm 1.1(1 \sigma)$ kbar; Maclennan et al. 2012; Winpenny and Maclennan 2011).

546 We identify two possible reasons for this discrepancy: firstly, we obtained few matches to the most 547 primitive clinopyroxenes $\left(\mathrm{Mg}_{\mathrm{cpx}}>90\right)$ that are most likely to have crystallized at high pressures; and 548 secondly, although the Putirka et al. (1996) barometer used by Winpenny and Maclennan (2011) 549 performed best at $8-10 \mathrm{kbar}$ when tested with experimental data (Figure 1a), it appears to converge 550 towards high pressures when performing iterative calculations on natural data (Supplementary Figure 1). 551 Assuming an average Icelandic crustal density of $2.86 \mathrm{Mg} \cdot \mathrm{m}^{-3}$ (Carlson and Herrick 1990), a storage 552 pressure of $4.8 \pm 1.8(1 \sigma)$ kbar corresponds to lower crustal depths of 13.7 $\pm 5.1(1 \sigma) \mathrm{km}$ (Moho depth $\sim 20$ $553 \mathrm{~km}$; Darbyshire et al. 2000).

555 Moderately primitive clinopyroxenes $\left(\mathrm{Mg \#}_{\mathrm{cpx}} \sim 80-86\right)$ in the Laki, Thjórsá and Skuggafjöll lavas, and the $55610 \mathrm{ka}$ Grímsvötn tephra series from the EVZ returned very similar mean pressures of 3.5-3.7 kbar with $5571 \sigma$ uncertainties of $1.5-1.8$ kbar. These values are broadly consistent with previous estimates of 2-5.4 558 kbar and 2.5-5.5 kbar for the Laki lava and $10 \mathrm{ka}$ Grímsvötn tephra series calculated by applying 559 empirical corrections to published barometers (Neave et al. 2013, 2015). Pressures of 3.5-3.7 kbar 560 correspond to mid-crustal depths of 10.0-10.6 $\pm 4.3-5.1(1 \sigma) \mathrm{km}$ (Moho depth $\sim 25-35 \mathrm{~km}$; Darbyshire et 561 al. 2000). More evolved clinopyroxenes $\left(\mathrm{Mg}_{\mathrm{cpx}}<80\right)$ from the same samples of the Laki and Thjórsá 562 lavas and the $10 \mathrm{ka}$ Grímsvötn tephra series returned slightly lower pressures of $2.5-2.8 \pm 1.5-1.7(1 \sigma)$

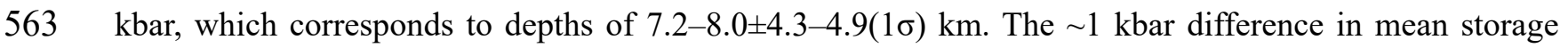
564 pressures between primitive and evolved clinopyroxene populations suggests that crystallization may 
565 have occurred at different depths. Indeed, pressures of final equilibration based on OPAM barometry

566 suggest that the evolved assemblage crystallized at low pressures (1-2 $\pm 1 \mathrm{kbar}$ ), though a low-pressure

567 overprint could have been imposed during final ascent (Neave et al. 2013, 2015).

569 Moderately primitive clinopyroxenes $\left(\mathrm{Mg} \#_{\mathrm{cpx}} \sim 80\right)$ from the Holuhraun 1 and 2 lavas returned the lowest 570 storage pressures of $2.4 \pm 1.7(1 \sigma) \mathrm{kbar}$, which are substantially lower than previously reported values (2.35717.6 kbar; Hartley and Thordarson 2013). The pressures we calculated from the Holuhraun 1 and 2 lavas 572 are also substantially lower than recent estimates from the petrologically analogous 2014-2015 573 Holuhraun lava (4.7 kbar; Geiger et al. 2016). These discrepancies probably reflect the inaccuracies in 574 previously published barometers (e.g., Supplementary Figure 1). Interestingly, a pressure of $2.4 \pm 1.7(1 \sigma)$ 575 kbar translates to a depth of $6.9 \pm 4.9(1 \sigma) \mathrm{km}$, which corresponds closely to the depth of dyke 576 emplacement during the 2014-2015 eruption (5-7 km; Ágústsdóttir et al. 2015) as well as to geodetically 577 inferred magma storage depths under the Bárðarbunga caldera (8-12 km; Gudmundsson et al. 2016).

\section{IMPLICATIONS}

580 The Accuracy and Precision of Jd-in-clinopyroxene Barometry

581 Tests performed on a range of clinopyroxene-liquid barometers reveal that currently published models 582 routinely overestimate the pressure of experimental clinopyroxene-liquid pairs at crustal storage 583 conditions, i.e., $\leq 7 \mathrm{kbar}$. The accuracy of current Jd-in-clinopyroxene barometers is pressure dependent, 584 with overestimates being greatest at $1 \mathrm{~atm}$. Although these tests were designed to investigate the accuracy 585 and precision of barometers at the conditions relevant to magma evolution under Iceland's rift zones (i.e., 586 the storage of low $-\mathrm{H}_{2} \mathrm{O}$ tholeiitic basalts), they demonstrate the importance of evaluating barometer 587 performance at the conditions of interest before interpreting any results (e.g., Masotta et al. 2013). 588 Therefore, numerous storage pressures calculated using clinopyroxene-liquid barometers may have been 589 overestimated by up to $3 \mathrm{kbar}$, and pressure estimates from MORB and OIB settings are likely to have 590 been affected with the greatest certainty. It may thus be necessary to reassess a number of published 
magma storage pressure estimates, particularly in situations where they are used to inform monitoring

592 strategies in volcanically active regions.

594 Our new Jd-in-clinopyroxene barometer offers a significant improvement in accuracy over previous

595 versions of the barometer: calibration data are reproduced with a high degree of accuracy and testing 596 against a global dataset reveals a maximum overestimation of $1.5 \mathrm{kbar}$ at $1 \mathrm{~atm}$; testing against 597 experiments on $\mathrm{H}_{2} \mathrm{O}$-poor tholeiites reveals a lower maximum overestimation of $1.2 \mathrm{kbar}$ at $1 \mathrm{~atm}$. 598 Although our new calibration is a substantial improvement on its forebears, it should nevertheless be 599 tested further as experimental databases continue to expand. The new barometer's precision (SEE $=1.4$ $600 \mathrm{kbar}$ ) is probably close to the limit of what can be achieved with the Jd-liquid reaction. It is thus essential 601 to consider the inherent imprecision of Jd-in-clinopyroxene barometers when interpreting calculation 602 results. For example, pressure distributions calculated from multiple analyses that approximate Gaussian 603 bell curves with standard deviations of $\sim 1.4$ kbar may only reflect model uncertainties rather than 604 polybaric distributions of magma storage. New approaches, such as integrating numerous mineral-mineral 605 and mineral-liquid thermobarometric equations, as is commonly undertaken in thermobarometric studies 606 of metamorphic rocks (Powell and Holland 2008), will probably be necessary to improve the barometric 607 precision in magmatic systems.

\section{Magma Storage Pressures under Iceland's Neovolcanic Rift Zones}

610 Our calculations provide an internally consistent insight into the storage pressures of a range of Icelandic 611 rift zone tholeiites. In line with previous observations, high-Mg\# clinopyroxenes from the Borgarhraun 612 lava record the highest pressures in our dataset $(4.8 \pm 1.8(1 \sigma)$ kbar; $13.7 \pm 5.1(1 \sigma) \mathrm{km})$, suggesting that near613 primary melts undergo substantial processing in the lower crust prior to eruption or intrusion to shallower 614 levels (Winpenny and Maclennan 2011). Indeed, patterns of microseismicity under the NVZ provide 615 strong evidence for the formation of intrusions in the lower crust (Hooper et al. 2011; Greenfield and 616 White 2015), where much of the initial compositional variability of primary mantle melts is probably 
617 destroyed by mixing (Maclennan 2008). However, the discrepancy between the pressures calculated here

$618(4.8 \pm 1.8(1 \sigma) \mathrm{kbar})$ and those reported previously $(8.1 \pm 1.1(1 \sigma) \mathrm{kbar})$ should be noted (Winpenny and

619 Maclennan 2011). Further experiments on primitive basalts should help to elucidate the causes of this

620 inconsistency, though an inability to identify equilibrium melts for highly primitive clinopyroxenes may

621 have also biased our calculations towards lower pressures. A storage pressure of $4.8 \pm 1.8(1 \sigma)$ kbar thus

622 represents a robust minimum value for the Borgarhraun magma.

623

624 Most of the eruption products we considered show evidence for crystallization in the Icelandic mid-crust.

625 Those containing compositionally bimodal clinopyroxene populations suggest that crystallization may

626 have occurred at two pressure intervals, 3.5-3.7 $\pm 1.5-1.8(1 \sigma)$ kbar and $2.5-2.8 \pm 1.5-1.7(1 \sigma)$ kbar.

627 However, given the large inherent uncertainties in Jd-in-clinopyroxene pressure estimates, it is currently

628 unclear whether these different pressures genuinely reflect polybaric crystallization. Nevertheless, the

629 conclusion that Icelandic rift zone tholeiites are primarily stored and processed in the mid-crust (2.5-3.7

630 kbar; 7.2-10.6 km) is robust. While a depth range of 7.2-10.6 km overlaps with some geodetic and

631 geophysical estimates of magma storage depths under Icelandic rift zones (Reverso et al. 2014;

632 Guðmundsson et al. 2016), many estimates from central volcanoes are significantly shallower (2-4 km;

633 Alfaro et al. 2007; de Zeeuw-van Dalfsen et al. 2012; Hreinsdóttir et al. 2014). However, with the

634 possible exception of the 10 ka Grímsvötn tephra series, none of the volcanic products we considered

635 were erupted from central volcanoes, indicating that they probably bypassed shallow storage zones en

636 route to the surface, as occurs in Hawai'i (Poland 2015).

638 Although our calculations compress the pressure ranges reported by previous studies using the same 639 clinopyroxene analyses (e.g., 2.8-3.8 kbar for Laki in contrast with 2.0-5.4 kbar; Neave et al. 2013), 640 integrating results across multiple eruptions and clinopyroxene populations indicates that magma storage 641 occurs across a range of depths under Icelandic rift zones (at least 2.5-4.8 kbar). Thus, accretion of the 642 Icelandic crust ostensibly proceeds in a similar manner to that outlined by stacked sill-type models from 
mid-ocean ridges (Boudier et al. 1996; Kelemen et al. 1997; Maclennan et al. 2001).

\section{ACKNOWLEDGEMENTS}

646 We thank Silvio Mollo and one anonymous reviewer for their helpful and constructive reviews, as well as

647 Georg Zellmer for his efficient editorial handling. DAN acknowledges support from the Alexander von

648 Humboldt Foundation.

\section{REFERENCES CITED}

651 Ágústsdóttir, T., Woods, J., Greenfield, T., Green, R.G., White, R.S., Brandsdóttir, B., Steinthorsson, S., and Soosalu, H. (2015) Episodic propagation of the 2014 Bárðarbunga-Holuhraun dike intrusion, central Iceland. Geophysical Research Letters, 43, 9.

Alfaro, R., Brandsdóttir, B., Rowlands, D.P., White, R.S., and Guðmundsson, M.T. (2007) Structure of the Grímsvötn central volcano under the Vatnajökull icecap, Iceland. Geophysical Journal International,

Almeev, R.R., Holtz, F., Koepke, J., Parat, F., and Botcharnikov, R.E. (2007) The effect of $\mathrm{H}_{2} \mathrm{O}$ on olivine crystallization in MORB: Experimental calibration at 200 MPa. American Mineralogist, 92, 670674.

Almeev, R.R., Holtz, F., Koepke, J., and Parat, F. (2012) Experimental calibration of the effect of $\mathrm{H}_{2} \mathrm{O}$ on plagioclase crystallization in basaltic melt at $200 \mathrm{MPa}$. American Mineralogist, 97, 1234-1240.

Annen, C., Blundy, J.D., and Sparks, R.S.J. (2006) The genesis of intermediate and silicic magmas in deep crustal hot zones. Journal of Petrology, 47, 505-539.

664 Barclay, J. (2004) A hornblende basalt from western Mexico: Water-saturated phase relations constrain a pressure-temperature window of eruptibility. Journal of Petrology, 45, 485-506.

Bartels, K.S., Kinzler, R.J., and Grove, T.L. (1991) High pressure phase relations of primitive highalumina basalts from Medicine Lake volcano, northern California. Contributions to Mineralogy and Petrology, 108, 253-270. 
Bender, J.F., Hodges, F.N., and Bence, A.E. (1978) Petrogenesis of basalts from the project FAMOUS area: experimental study from 0 to 15 kbars. Earth and Planetary Science Letters, 41, 277-302.

671 Berndt, J., Holtz, F., and Koepke, J. (2001) Experimental constraints on storage conditions in the 672 chemically zoned phonolitic magma chamber of the Laacher See volcano. Contributions to 673 Mineralogy and Petrology, 140, 469-486.

674 Berndt, J., Liebske, C., Holtz, F., Freise, M., Nowak, M., Ziegenbein, D., Hurkuck, W., and Koepke, J. 675 (2002) A combined rapid-quench and $\mathrm{H}_{2}$-membrane setup for internally heated pressure vessels: 676 Description and application for water solubility in basaltic melts. American Mineralogist, 87, 1717$677 \quad 1726$

678 Berndt, J., Koepke, J., and Holtz, F. (2005) An experimental investigation of the influence of water and oxygen fugacity on differentiation of MORB at $200 \mathrm{MPa}$. Journal of Petrology, 46, 135-167.

Blatter, D.L., and Carmichael, I.S.E. (2001) Hydrous phase equilibria of a Mexican high-silica andesite: A candidate for a mantle origin? Geochimica et Cosmochimica Acta, 65, 4043-4065.

Blundy, J.D., and Cashman, K. V. (2008) Petrologic reconstruction of magmatic system variables and processes. Reviews in Mineralogy and Geochemistry, 69, 179-239.

684 Blundy, J.D., Falloon, T.J., Wood, B.J., and Dalton, J.A. (1995) Sodium partitioning between clinopyroxene and silicate melts. Journal of Geophysical Research: Solid Earth, 100, 15501-15515.

Botcharnikov, R.E., Almeev, R.R., Koepke, J., and Holtz, F. (2008) Phase relations and liquid lines of descent in hydrous ferrobasalt - Implications for the Skaergaard intrusion and Columbia River flood basalts. Journal of Petrology, 49, 1687-1727.

Boudier, F., Nicolas, A., and Ildefonse, B. (1996) Magma chambers in the Oman ophiolite: fed from the top and the bottom. Earth and Planetary Science Letters, 144, 239-250.

Bucholz, C.E., Gaetani, G.A., Behn, M.D., and Shimizu, N. (2013) Post-entrapment modification of volatiles and oxygen fugacity in olivine-hosted melt inclusions. Earth and Planetary Science Letters,

694 Budd, D.A., Troll, V.R., Dahren, B., and Burchardt, S. (2016) Persistent two-tiered magma plumbing 
beneath Katla volcano, Iceland. Geochemistry, Geophysics, Geosystems, 17, 966-980.

696 Bulatov, V.K., Girnis, A. V., and Brey, G.P. (2002) Experimental melting of a modally heterogeneous

697 mantle. Mineralogy and Petrology, 75, 131-152.

698 Carlson, R.L., and Herrick, C.N. (1990) Densities and porosities in the oceanic crust and their variations

699 with depth and age. Journal of Geophysical Research, 95, 9153-9170.

700 Cashman, K. V., and Sparks, R.S.J. (2013) How volcanoes work: A 25 year perspective. Bulletin of the 701 Geological Society of America, 125, 664-690.

702 Chatterjee, N., Bhattacharji, S., and Fein, C. (2005) Depth of alkalic magma reservoirs below Kolekole 703 cinder cone, Southwest rift zone, East Maui, Hawaii. Journal of Volcanology and Geothermal $704 \quad$ Research, 145, 1-22.

705 Cottrell, E., and Kelley, K.A. (2011) The oxidation state of Fe in MORB glasses and the oxygen fugacity 706 of the upper mantle. Earth and Planetary Science Letters, 305, 270-282.

Dann, J.C., Holzheid, A.H., Grove, T.L., and McSween, H.Y. (2001) Phase equilibria of the Shergotty meteorite: Constraints on pre-eruptive water contents of martian magmas and fractional crystallization under hydrous conditions. Meteoritics \& Planetary Science, 36, 793-806.

Darbyshire, F.A., White, R.S., and Priestley, K.F. (2000) Structure of the crust and uppermost mantle of Iceland from a combined seismic and gravity study. Earth and Planetary Science Letters, 181, 409-

de Zeeuw-van Dalfsen, E., Pedersen, R., Hooper, A., and Sigmundsson, F. (2012) Subsidence of Askja 428. caldera 2000-2009: Modelling of deformation processes at an extensional plate boundary, constrained by time series InSAR analysis. Journal of Volcanology and Geothermal Research, 213$214,72-82$.

Di Carlo, I., Pichavant, M., Rotolo, S.G., and Scaillet, B. (2006) Experimental crystallization of a high-K arc basalt: The golden pumice, Stromboli volcano (Italy). Journal of Petrology, 47, 1317-1343.

Dixon, J.E., and Stolper, E.M. (1995) An experimental study of water and carbon dioxide solubilities in mid-ocean ridge basaltic liquids. Part I: Calibration and Solubility Models. Journal of Petrology, 36, 
1633-1646.

722 Downes, M.J. (1974) Sector and oscillatory zoning in calcic augites from M. Etna, Sicily. Contributions 723 to Mineralogy and Petrology, 47, 187-196.

724 Draper, D.S., and Green, T.H. (1999) P-T phase relations of silicic, alkaline, aluminous liquids: New

725 results and applications to mantle melting and metasomatism. Earth and Planetary Science Letters, $726 \quad 170,255-268$.

727 Edmonds, M. (2008) New geochemical insights into volcanic degassing. Philosophical Transactions of 728 the Royal Society A: Mathematical, Physical and Engineering Sciences, 366, 4559-4579.

729 Elkins-Tanton, L.T., and Grove, T.L. (2003) Evidence for deep melting of hydrous metasomatized mantle:

730 Pliocene high-potassium magmas from the Sierra Nevadas. Journal of Geophysical Research, 108, 7312350.

732 Falloon, T.J., Green, D.H., O’Neill, H.S.C., and Hibberson, W.O. (1997) Experimental tests of low degree 733 peridotite partial melt compositions: implications for the nature of anhydrous near-solidus peridotite 734 melts at $1 \mathrm{GPa}$. Earth and Planetary Science Letters, 152, 149-162.

735 Falloon, T.J., Green, D.H., Danyushevsky, L. V., and Faul, U.H. (1999) Peridotite Melting at 1.0 and 1.5

736 GPa: An Experimental Evaluation of Techniques using Diamond Aggregates and Mineral Mixes for 737 Determination of Near-solidus Melts. Journal of Petrology, 40, 1343-1375.

738 Falloon, T.J., Danyushevsky, L. V., and Green, D.H. (2001) Peridotite Melting at 1 GPa: Reversal

739 Experiments on Partial Melt Compositions Produced by Peridotite-Basalt Sandwich Experiments.

$740 \quad$ Journal of Petrology, 42, 2363-2390.

741 Gaetani, G.A., and Grove, T.L. (1998) The influence of water on melting of mantle peridotite.

742 Contributions to Mineralogy and Petrology, 131, 323-346.

743 Ganino, C., Arndt, N.T., Chauvel, C., Jean, A., and Athurion, C. (2013) Melting of carbonate wall rocks

744 and formation of the heterogeneous aureole of the Panzhihua intrusion, China. Geoscience Frontiers, $745 \quad 4,535-546$.

746 Geiger, H., Mattsson, T., Deegan, F.M., Troll, V.R., Burchardt, S., Gudmundsson, Ó., Tryggvason, A., 
Krumbholz, M., and Harris, C. (2016) Magma plumbing for the 2014-2015 Holuhraun eruption, Iceland. Geochemistry, Geophysics, Geosystems, 17, 1-16.

Giacomoni, P.P., Coltorti, M., Bryce, J.G., Fahnestock, M.F., and Guitreau, M. (2016) Mt. Etna plumbing system revealed by combined textural, compositional, and thermobarometric studies in

Greenfield, T., and White, R.S. (2015) Building icelandic igneous crust by repeated melt injections. clinopyroxenes. Contributions to Mineralogy and Petrology, 171, 34. Journal of Geophysical Research: Solid Earth, 120, 7771-7788.

Grove, T.L., Kinzler, R.J., and Bryan, W.B. (1992) Fractionation of Mid-Ocean Ridge Basalt (MORB).

Grove, T.L., Donnelly-Nolan, J.M., and Housh, T. (1997) Magmatic processes that generated the rhyolite Mantle Flow and Melt Generation at Mid-Ocean Ridges, Geophysical Monograph 71, American

Grove, T.L., Elkins-Tanton, . T., Parman, S.W., Chatterjee, N., Müntener, O., and Gaetani, G.A. (2003) Fractional crystallization and mantle-melting controls on calc-alkaline differentiation trends. Contributions to Mineralogy and Petrology, 145, 515-533.

Guðmundsson, M.T., Jónsdóttir, K., Hooper, A., Holohan, E.P., Halldórsson, S.A., Ófeigsson, B.G., Cesca, S., Vogfjörd, K.S., Sigmundsson, F., Högnadóttir, T., and others (2016) Gradual caldera

Halldórsson, S.A., Óskarsson, N., Sigurdsson, G., Sverrisdottir, G., and Steinthórsson, S. (2008) Isotopicheterogeneity of the Thjorsa lava-Implications for mantle sources and crustal processes within the Eastern Rift Zone, Iceland. Chemical Geology, 255, 305-316.

Hammer, J.E., Jacob, S., Welsch, B., Hellebrand, E., and Sinton, J.M. (2016) Clinopyroxene in postshield Haleakala ankaramite 1. Efficacy of thermobarometry. Contributions to Mineralogy and Petrology.

Hansen, H., and Grönvold, K. (2000) Plagioclase ultraphyric basalts in Iceland: The mush of the rift. Journal of Volcanology and Geothermal Research, 98, 1-32. 
Hansteen, T.H., and Klügel, A. (2008) Fluid Inclusion Thermobarometry as a Tracer for Magmatic Processes. Reviews in Mineralogy and Geochemistry, 69, 143-177.

Hansteen, T.H., Klügel, A., and Schmincke, H.-U. (1998) Multi-stage magma ascent beneath the Canary Islands: evidence from fluid inclusions. Contributions to Mineralogy and Petrology, 132, 48-64.

Hartley, M.E., and Thordarson, T. (2013) The 1874-1876 volcano-tectonic episode at Askja, North Iceland: Lateral flow revisited. Geochemistry, Geophysics, Geosystems, 14, 2286-2309.

Hartley, M.E., Maclennan, J., Edmonds, M., and Thordarson, T. (2014) Reconstructing the deep $\mathrm{CO}_{2}$ degassing behaviour of large basaltic fissure eruptions. Earth and Planetary Science Letters, 393,

Henstock, T.J., Woods, A.W., and White, R.S. (1993) The accretion of oceanic crust by episodic sill intrusion. Journal of Geophysical Research, 98, 4143.

Hill, E., Blundy, J.D., and Wood, B.J. (2011) Clinopyroxene-melt trace element partitioning and the development of a predictive model for HFSE and Sc. Contributions to Mineralogy and Petrology,

Holland, T.J.B., and Powell, R. (1998) An internally consistent thermodynamic data set for phases of petrological interest. Journal of Metamorphic Geology, 16, 309-343.

Holloway, J.R., Dixon, J.E., and Pawley, A. (1992) An internally heated, rapid-quench, high-pressure vessel. American Mineralogist, 77, 643-646.

Hooper, A., Ófeigsson, B., Sigmundsson, F., Lund, B., Einarsson, P., Geirsson, H., and Sturkell, E. (2011)

Husen, A., Almeev, R.R., and Holtz, F. (2016) The Effect of H2O and Pressure on Multiple Saturation and Liquid Lines of Descent in Basalt from the Shatsky Rise. Journal of Petrology, 57, 309-344. 
Johnson, K.T.M. (1998) Experimental determination of partition coefficients for rare earth and high-fieldstrength elements between clinopyroxene, garnet, and basaltic melt at high pressures. Contributions to Mineralogy and Petrology, 133, 60-68.

Johnston, A.D. (1986) Anhydrous P-T phase relations of near-primary high-alumina basalt from the South

803 Sandwich Islands - Implications for the origin of island arcs and tonalite-trondhjemite series rocks.

804 Contributions to Mineralogy and Petrology, 92, 368-382.

805 Jude-Eton, T.C., Thordarson, T., Guðmundsson, M.T., and Oddsson, B. (2012) Dynamics, stratigraphy

806 and proximal dispersal of supraglacial tephra during the ice-confined 2004 eruption at Grímsvötn

807 Volcano, Iceland. Bulletin of Volcanology, 74, 1057-1082.

808 Kägi, R., Müntener, O., Ulmer, P., and Ottolini, L. (2005) Piston-cylinder experiments on $\mathrm{H}_{2} \mathrm{O}$

809 undersaturated Fe-bearing systems: An experimental setup approaching $\mathrm{fO}_{2}$ conditions of natural

$810 \quad$ calc-alkaline magmas. American Mineralogist, 90, 708-717.

811 Keiding, J.K., and Sigmarsson, O. (2012) Geothermobarometry of the 2010 Eyjafjallajökull eruption:

812 New constraints on Icelandic magma plumbing systems. Journal of Geophysical Research: Solid

$813 \quad$ Earth, 117, 1-15.

814 Kelemen, P.B., Joyce, D.B., Webster, J.D., and Holloway, J.R. (1990) Reaction between Ultramafic Rock

815 and Fractionationg Basaltic Magma II: Experimental Investigation of Reaction Between Olivine

816 Tholeiite and Hartburgite at $1150-1050^{\circ} \mathrm{C}$ and 5 kb. Jour. Petrol., 31, 99-134.

817 Kelemen, P.B., Koga, K.T., and Shimizu, N. (1997) Geochemistry of gabbro sills in the crust-mantle

818 transition zone of the Oman ophiolite: Implications for the origin of the oceanic lower crust. Earth

819 and Planetary Science Letters, 146, 475-488.

820 Kinzler, R.J. (1997) Melting of mantle peridotite at pressures approaching the spinel to garnet transition:

821 Application to mid-ocean ridge basalt petrogenesis. Journal of Geophysical Research: Solid Earth, $822 \quad 102,853-874$.

823 Kinzler, R.J., and Grove, T.L. (1992) Primary magmas of mid-ocean ridge basalts 1. Experiments and 824 Methods. Journal of Geophysical Research, 97, 6907. 
Klügel, A., Hansteen, T.H., and Galipp, K. (2005) Magma storage and underplating beneath Cumbre Vieja volcano, La Palma (Canary Islands). Earth and Planetary Science Letters, 236, 211-226.

827 Kogiso, T., and Hirschmann, M.M. (2001) Experimental study of clinopyroxenite partial melting and the 828 origin of ultra-calcic melt inclusions. Contributions to Mineralogy and Petrology, 142, 347-360.

829 Kogiso, T., Hirose, K., and Takahashi, E. (1998) Melting experiments on homogeneous mixtures of 830 peridotite and basalt: Application to the genesis of ocean island basalts. Earth and Planetary Science $831 \quad$ Letters, $162,45-61$.

832 Koornneef, J.M., Stracke, A., Bourdon, B., Meier, M.A., Jochum, K.P., Stoll, B., and Grönvold, K. (2012)

833 Melting of a two-component source beneath Iceland. Journal of Petrology, 53, 127-157.

834 Kouchi, A., Sugawara, Y., Kashima, K., and Sunagawa, I. (1983) Laboratory growth of sector zones 835 clinopyroxenes in the system CaMgSi206-CaTiA1206. Contributions to Mineralogy and Petrology, $836 \quad 83,177-184$.

Laporte, D., Toplis, M.J., Seyler, M., and Devidal, J.-L. (2004) A new experimental technique for extracting liquids from peridotite at very low degrees of melting: Application to partial melting of depleted peridotite. Contributions to Mineralogy and Petrology, 146, 463-484.

Macdonald, R., Sumita, M., Schmincke, H.U., Bagiński, B., White, J.C., and Ilnicki, S.S. (2015)

Maclennan, J., McKenzie, D., Grönvold, K., and Slater, L. (2001) Crustal accretion under Northern Peralkaline felsic magmatism at the Nemrut volcano, Turkey: impact of volcanism on the evolution Iceland. Earth and Planetary Science Letters, 191, 295-310.

Maclennan, J. (2008) Concurrent mixing and cooling of melts under Iceland. Journal of Petrology, 49, of Lake Van (Anatolia) IV. Contributions to Mineralogy and Petrology, 169. in a single flow from northern Iceland. Journal of Geophysical Research, 108, 1-21. 
Maclennan, J., McKenzie, D., Grönvold, K., Shimizu, N., Eiler, J.M., and Kitchen, N. (2003b) Melt mixing and crystallization under Theistareykir, northeast Iceland. Geochemistry, Geophysics,

854 Maclennan, J., Gaetani, G.A., Hartley, M.E., Neave, D.A., and Winpenny, B. (2012) Petrological constraints on the crustal structure under rift zones. In AGU Fall Meeting Abstracts p. T41G.

Masotta, M., Mollo, S., Freda, C., Gaeta, M., and Moore, G. (2013) Clinopyroxene-liquid thermometers

Meen, J.K. (1990) Elevation of potassium content by fractional crystallization: the effect of pressure.

Médard, E., McCammon, C.A., Barr, J.A., and Grove, T.L. (2008) Oxygen fugacity, temperature reproducibility, and $\mathrm{H} 2 \mathrm{O}$ contents of nominally anhydrous piston-cylinder experiments using

Michael, P.J. (1995) Evidence from trace elements and $\mathrm{H}_{2} \mathrm{O}$ for regionally distinctive sources of depleted

Mollo, S., Putirka, K.D., Misiti, V., Soligo, M., and Scarlato, P. (2013a) A new test for equilibrium based on clinopyroxene-melt pairs: Clues on the solidification temperatures of Etnean alkaline melts at post-eruptive conditions. Chemical Geology, 352, 92-100.

Mollo, S., Blundy, J.D., Iezzi, G., Scarlato, P., and Langone, A. (2013b) The partitioning of trace elements between clinopyroxene and trachybasaltic melt during rapid cooling and crystal growth. Contributions to Mineralogy and Petrology, 166, 1633-1654.

Moore, G. (2008) Interpreting H2O and CO2 Contents in Melt Inclusions: Constraints from Solubility Experiments and Modeling. Reviews in Mineralogy and Geochemistry, 69, 333-362. 
877 Moore, G., and Carmichael, I.S.E. (1998) The hydrous phase equilibria (to 3 kbar) of an andesite and 878 basaltic andesite from western Mexico: constraints on water content and conditions of phenocryst 879 growth. Contributions to Mineralogy and Petrology, 130, 304-319.

880 Moore, G., Roggensack, K., and Klonowski, S. (2008) A low-pressure-high-temperature technique for the 881 piston-cylinder. American Mineralogist, 93, 48-52.

882 Moore, L.R., Gazel, E., Tuohy, R., Lloyd, A.S., Epsosito, R., Steele-MacInnis, M.J., Hauri, E.H., Wallace, 883 P.J., Plank, T., and Bodnar, R.J. (2015) Bubbles matter: An assessment of the contribution of vapor 884 bubbles to melt inclusion volatile budgets. American Mineralogist, 100, 806-823.

885 Müntener, O., Kelemen, P.B., and Grove, T.L. (2001) The role of H2O during crystallization of primitive 886 arc magmas under uppermost mantle conditions and genesis of igneous pyroxenites: an 887 experimental study. Contributions to Mineralogy and Petrology, 141, 643-658.

888 Nakamura, Y. (1973) Origin of sector-zoning of igneous clinopyroxenes. American Mineralogist, 58, 986-990.

890 Neave, D.A., Passmore, E., Maclennan, J., Fitton, J.G., and Thordarson, T. (2013) Crystal-melt

891 relationships and the record of deep mixing and crystallization in the AD 1783 Laki eruption, 892 Iceland. Journal of Petrology, 54, 1661-1690.

893 Neave, D.A., Maclennan, J., Hartley, M.E., Edmonds, M., and Thordarson, T. (2014) Crystal storage and 894 transfer in basaltic systems: the Skuggafjöll eruption, Iceland. Journal of Petrology, 55, 2311-2346.

895 Neave, D.A., Maclennan, J., Thordarson, T., and Hartley, M.E. (2015) The evolution and storage of 896 primitive melts in the Eastern Volcanic Zone of Iceland: the 10 ka Grímsvötn tephra series (i.e. the 897 Saksunarvatn ash). Contributions to Mineralogy and Petrology, 170, 1-23.

898 Newman, S., and Lowenstern, J.B. (2002) Volatile Calc: a silicate melt- $\mathrm{H}_{2} \mathrm{O}-\mathrm{CO}_{2}$ solution model written 899 in Visual Basic for excel. Computers and Geosciences, 28, 597-604.

900 Nimis, P. (1995) A clinopyroxene geobarometer for basaltic systems based on crystal-structure modeling. 901 Contributions to Mineralogy and Petrology, 121, 115-125.

902 Parman, S.W., and Grove, T.L. (2004) Harzburgite melting with and without $\mathrm{H}_{2} \mathrm{O}$ : experimental data and 
predictive modeling. Journal of Geophysical Research, 109, 1-20.

904 Passmore, E. (2009) Feeding large eruptions: crystallisation, mixing and degassing in Icelandic magma 905 chambers. University of Edinburgh.

906 Patiño-Douce, A.E., and Beard, J.S. (1996) Effects of $\mathrm{P}, f\left(\mathrm{O}_{2}\right)$ and $\mathrm{Mg} / \mathrm{Fe}$ Ratio on Dehydration Melting 907 of Model Metagreywackes. Journal of Petrology, 37, 999-1024.

908 Pichavant, M., Martel, C., Bourdier, J.-L., and Scaillet, B. (2002) Physical conditions, structure, and 909 dynamics of a zoned magma chamber: Mount Pelée (Martinique, Lesser Antilles Arc). J. Geophys. $910 \quad$ Res., 107, 2093.

911 Pickering-Witter, J., and Johnston, A.D. (2000) The effects of variable bulk composition on the melting 912 systematics of fertile peridotitic assemblages. Contributions to Mineralogy and Petrology, 140, 190913211.

914 Poland, M.P. (2015) “Points Requiring Elucidation” About Hawaiian Volcanism. In R.J. Carey, R.A.

915 Cayley, M.P. Poland, and D. Weis, Eds., Hawaiian Volcanoes: From Source to Surface, Geophysical 916 Monograph, American Geophysical Union pp. 533-562. John Wiley \& Sons, Inc., Oxford.

917 Powell, R., and Holland, T.J.B. (2008) On thermobarometry. Journal of Metamorphic Geology, 26, 155$918 \quad 179$.

919 Putirka, K.D. (1999) Clinopyroxene + liquid equilibria to $100 \mathrm{kbar}$ and 2450 K. Contributions to $920 \quad$ Mineralogy and Petrology, 135, 151-163.

921 (2008) Thermometers and Barometers for Volcanic Systems. Reviews in Mineralogy and 922 Geochemistry, 69, 61-120.

923 (2016) Amphibole thermometers and barometers for igneous systems, and some implications for 924 eruption mechanisms of felsic magmas at arc volcanoes. American Mineralogist.

925 Putirka, K.D., Johnson, M., Kinzler, R.J., Longhi, J., and Walker, D. (1996) Thermobarometry of mafic 926 igneous rocks based on clinopyroxene-liquid equilibria, 0-30 kbar. Contributions to Mineralogy and 927 Petrology, 123, 92-108.

928 Putirka, K.D., Mikaelian, H., Ryerson, F., and Shaw, H.F. (2003) New clinopyroxene-liquid 
thermobarometers for mafic, evolved, and volatile-bearing lava compositions, with applications to lavas from Tibet and the Snake River Plain, Idaho. American Mineralogist, 88, 1542-1554.

931 Reverso, T., Vandemeulebrouck, J., Jouanne, F., Pinel, V., Villemin, T., Sturkell, E., and Bascou, P. (2014) 932 A two-magma chamber model as a source of deformation at Grímsvötn Volcano, Iceland. Journal of 933 Geophysical Research: Solid Earth, 119, 4666-4683.

934 Robinson, J.A.C., Wood, B.J., and Blundy, J.D. (1998) The beginning of melting of fertile and depleted 935 peridotite at $1.5 \mathrm{GPa}$. Earth and Planetary Science Letters, 155, 97-111.

936 Rudge, J.F. (2008) Finding peaks in geochemical distributions: A re-examination of the helium937 continental crust correlation. Earth and Planetary Science Letters, 274, 179-188.

938 Schwab, B.E., and Johnston, A.D. (2001) Melting Systematics of Modally Variable, Compositionally 939 Intermediate Peridotites and the Effects of Mineral Fertility. J. Petrol., 42, 1789-1811.

940 Scoates, J.S., Lo Cascio, M., Weis, D., and Lindsley, D.H. (2006) Experimental constraints on the origin and evolution of mildly alkalic basalts from the Kerguelen Archipelago, Southeast Indian Ocean.

943 Shishkina, T.A., Botcharnikov, R.E., Holtz, F., Almeev, R.R., Jazwa, A.M., and Jakubiak, A.A. (2014)

944 Compositional and pressure effects on the solubility of $\mathrm{H}_{2} \mathrm{O}$ and $\mathrm{CO}_{2}$ in mafic melts. Chemical 945 Geology, 388, 112-129.

946 Shorttle, O., and Maclennan, J. (2011) Compositional trends of Icelandic basalts: Implications for short947 length scale lithological heterogeneity in mantle plumes. Geochemistry, Geophysics, Geosystems, $948 \quad 12,1-32$.

949 Shorttle, O., Moussallam, Y., Hartley, M.E., Maclennan, J., Edmonds, M., and Murton, B.J. (2015) Fe950 XANES analyses of Reykjanes Ridge basalts: Implications for oceanic crust's role in the solid Earth $951 \quad$ oxygen cycle. Earth and Planetary Science Letters, 427, 272-285.

952 Sigmundsson, F., Hreinsdóttir, S., Hooper, A., Arnadóttir, T., Pedersen, R., Roberts, M.J., Óskarsson, N., 953 Decriem, J., Einarsson, P., Geirsson, H., and others (2010) Intrusion triggering of the 2010

954 Eyjafjallajökull explosive eruption. Nature, 468, 426-430. 
Sigurdsson, I.A., Steinthórsson, S., and Grönvold, K. (2000) Calcium-rich melt inclusions in Cr-spinels from Borgarhraun, northern Iceland. Earth and Planetary Science Letters, 183, 15-26.

957 Singh, S.C., Crawford, W.C., Carton, H., Seher, T., Combier, V., Cannat, M., Pablo Canales, J., Düşünür, 958 D., Escartín, J., and Miranda, J.M. (2006) Discovery of a magma chamber and faults beneath a Mid$959 \quad$ Atlantic Ridge hydrothermal field. Nature, 442, 1029-1032.

960 Sisson, T.W., and Grove, T.L. (1993) Experimental investigations of the role of $\mathrm{H}_{2} \mathrm{O}$ in calc-alkaline 961 differentiation and subduction zone magmatism. Contributions to Mineralogy and Petrology, 113, 962 143-166.

963 Slater, L., McKenzie, D., Grönvold, K., and Shimizu, N. (2001) Melt generation and movement beneath 964 Theistareykir, NE Iceland. Journal of Petrology, 42, 321-354.

965 Streeter, R., and Dugmore, A. (2014) Late-Holocene land surface change in a coupled social-ecological 966 system, southern Iceland: A cross-scale tephrochronology approach. Quaternary Science Reviews, $967 \quad 86,99-114$.

968 Stroncik, N.A., Klügel, A., and Hansteen, T.H. (2009) The magmatic plumbing system beneath El Hierro

969 (Canary Islands): Constraints from phenocrysts and naturally quenched basaltic glasses in submarine $970 \quad$ rocks. Contributions to Mineralogy and Petrology, 157, 593-607.

971 Strong, D.F. (1969) Formation of the hour-glass structure in augite. Mineralogical Magazine, 37, 472972479.

973 Takahahshi, E., Nakajima, K., and Wright, T.L. (1998) Origin of the Columbia River basalts: Melting 974 model of a heterogeneous plume head. Earth and Planetary Science Letters, 162, 63-80.

975 Tarasewicz, J., White, R.S., Brandsdottir, B., and Schoonman, C.M. (2014) Seismogenic magma intrusion 976 before the 2010 eruption of Eyjafjallajokull volcano, Iceland. Geophysical Journal International, $977 \quad 198,906-921$.

978 Thomson, A., and Maclennan, J. (2013) The distribution of olivine compositions in icelandic basalts and 979 picrites. Journal of Petrology, 54, 745-768.

980 Thy, P., Lesher, C.E., Nielsen, T.F.D., and Brooks, C.K. (2006) Experimental constraints on the 
Skaergaard liquid line of descent. Lithos, 92, 154-180.

982 Toplis, M.J., and Carroll, M.R. (1995) An Experimental Study of the Influence of Oxygen Fugacity on

983 Fe-Ti Oxide Stability, Phase Relations, and Mineral-Melt Equilibria in Ferro-Basaltic Systems.

$984 \quad$ Journal of Petrology, 36, 1137-1170.

985 Tormey, D.R., Grove, T.L., and Bryan, W.B. (1987) Experimental petrology of normal MORB near the

986 Kane Fracture Zone: $22^{\circ}-25^{\circ}$ N, mid-Atlantic ridge. Contributions to Mineralogy and Petrology, 96 ,

$987 \quad 121-139$.

988 Vander Auwera, J., and Longhi, J. (1994) Experimental study of a jotunite (hypersthene monzodiorite):

989 constraints on the parent magma composition and crystallization conditions $(\mathrm{P}, \mathrm{T}, \mathrm{fO} 2)$ of the

990 Bjerkreim-Sokndal layered intrusion (Norway). Contributions to Mineralogy and Petrology, 118,

$991 \quad 60-78$.

992 Vander Auwera, J., Longhi, J., and Duchesne, J.-C. (1998) A liquid line of descent of the jotunite

993 (Hypersthene monzodiorite) suite. Journal of Petrology, 39, 439-468.

994 Villiger, S., Ulmer, P., Müntener, O., and Thompson, A.B. (2004) The liquid line of descent of anhydrous,

995 mantle-derived, tholeiitic liquids by fractional and equilibrium crystallization - An experimental

996 study at 1.0 GPa. Journal of Petrology, 45, 2369-2388.

997 Villiger, S., Ulmer, P., and Müntener, O. (2007) Equilibrium and fractional crystallization experiments at

$998 \quad 0.7 \mathrm{GPa}$; the effect of pressure on phase relations and liquid compositions of tholeiitic magmas.

999 Journal of Petrology, 48, 159-184.

1000 Wallace, P.J., Kamenetsky, V.S., and Cervantes, P. (2015) Melt inclusion $\mathrm{CO}_{2}$ contents, pressures of

1001 olivine crystallization, and the problem of shrinkage bubbles. American Mineralogist, 100, 787-794.

1002 Wasylenki, L.E., Baker, M.B., Kent, A.J.R., and Stolper, E.M. (2003) Near-solidus Melting of the

1003 Shallow Upper Mantle: Partial Melting Experiments on Depleted Peridotite. Journal of Petrology,

$1004 \quad 44,1163-1191$.

1005 Welsch, B., Hammer, J.E., Baronnet, A., Jacob, S., Hellebrand, E., and Sinton, J.M. (2016) Clinopyroxene

1006 in postshield Haleakala ankaramite 2. Texture, compositional zoning, and supersaturation in the 
magma. Contributions to Mineralogy and Petrology.

1008 Whitaker, M.L., Nekvasil, H., Lindsley, D.H., and Difrancesco, N.J. (2007) The role of pressure in 1009 producing compositional diversity in intraplate basaltic magmas. Journal of Petrology, 48, 365-393.

1010 Whitaker, M.L., Nekvasil, H., Lindsley, D.H., and McCurry, M. (2008) Can crystallization of olivine 1011 tholeiite give rise to potassic rhyolites? - An experimental investigation. Bulletin of Volcanology, 70, $1012 \quad 417-434$.

1013 Winpenny, B., and Maclennan, J. (2011) A partial record of mixing of mantle melts preserved in icelandic 1014 phenocrysts. Journal of Petrology, 52, 1791-1812.

1015 Wood, B.J., and Blundy, J.D. (1997) A predictive model for rare earth element partitioning between 1016 clinopyroxene and anhydrous silicate melt. Contributions to Mineralogy and Petrology, 129, 166$1017 \quad 181$.

1018 Yang, H.-J., Kinzler, R.J., and Grove, T.L. (1996) Experiments and models of anhydrous, basaltic olivine1019 plagioclase-augite saturated melts from 0.001 to $10 \mathrm{kbar}$. Contributions to Mineralogy and $1020 \quad$ Petrology, 124, 1-18.

1021 Yoder, H.J., and Tilley, C.E. (1962) Origin of Basalt Magmas: an Experimental Study of Natural and 1022 Synthetic Rocks Systems. Journal of Petrology, 3, 342-532.

1023 Zellmer, G.F., Sakamoto, N., Iizuka, Y., Miyoshi, M., Tamura, Y., Hsieh, H.-H., and Yurimoto, H. (2014)

1024 Crystal uptake into aphyric arc melts: insights from two-pyroxene pseudo-decompression paths, 1025 plagioclase hygrometry, and measurement of hydrogen in olivines from mafic volcanics of SW 1026 Japan. Geological Society, London, Special Publications, 385, 161-184. 
1028 Figure 1 Tests performed on published clinopyroxene-liquid barometers with data from experiments 1029 carried out on $\mathrm{H}_{2} \mathrm{O}$-poor tholeiites (dark red points). Test data were collated from the following sources: 1030 Berndt et al. (2005), Botcharnikov et al. (2008), Grove et al. (1992), Husen et al. (2016), Thy et al. 1031 (2006), Toplis and Carroll (1995), Villiger et al. (2004, 2007), Whitaker et al. (2007, 2008) and Yang et al. 1032 (1996). One-to-one lines between experimental and calculated pressures are shown in pale grey.

1033 Regression lines through the test dataset are shown in black. Data from Villiger et al. $(2004,2007)$ and 1034 composition 70-002 from Grove et al. (1992) that were excluded from the regressions used to summarize 1035 barometer performance are shown in grey. The following barometers were tested: (a) model P1 from 1036 Putirka et al. (1996), a Jd-in-clinopyroxene barometer; (b) equation 30 from Putirka (2008), a Jd-in1037 clinopyroxene barometer; (c) equation 32a from Putirka (2008), a clinopyroxene composition barometer; 1038 and (d) equation 32c from Putirka (2008), an Al partitioning barometer.

1040 Figure 2 Calibration of a new Jd-in-clinopyroxene barometer. The barometer's abilities to reproduce 1041 experimental pressures with (a) imposed and (b) iteratively calculated temperatures are shown, alongside 1042 (c) the ability of equation 33 from Putirka (2008) to reproduce experimental temperatures during iterative 1043 calculations. The new barometer is directly compared with model P1 from Putirka et al. (1996) in (d). 1044 Note that the new barometer faithfully reproduces the pressure of a wider range of 1 atm experiments than 1045 model P1 from Putirka et al. (1996).

1047 Figure 3 Tests performed on the new Jd-in-clinopyroxene barometer using a global dataset of 1048 clinopyroxene-saturated experiments performed at $\leq 20 \mathrm{kbar}$ (Bender et al. 1978; Johnston 1986; Kelemen 1049 et al. 1990; Meen 1990; Bartels et al. 1991; Vander Auwera and Longhi 1994; Patiño-Douce and Beard 1050 1996; Falloon et al. 1999, 2001; Grove et al. 1997, 2003; Kinzler 1997; Falloon et al. 1997; Gaetani and 1051 Grove 1998; Johnson 1998; Kogiso et al. 1998; Robinson et al. 1998; Takahahshi et al. 1998; Vander 1052 Auwera et al. 1998; Draper and Green 1999; Pickering-Witter and Johnston 2000; Kogiso and 1053 Hirschmann 2001; Müntener et al. 2001; Berndt et al. 2001; Schwab and Johnston 2001; Dann et al. 
1054 2001; Pichavant et al. 2002; Bulatov et al. 2002; Wasylenki et al. 2003; Elkins-Tanton and Grove 2003;

1055 Barclay 2004; Laporte et al. 2004; Médard et al. 2004; Parman and Grove 2004; Kägi et al. 2005; Scoates

1056 et al. 2006; Di Carlo et al. 2006; Ganino et al. 2013). The barometer's abilities to reproduce experimental

1057 pressures with (a) imposed temperatures and (b) iteratively calculated temperatures are shown. High- $f \mathrm{O}_{2}$

1058 experiments on phonolitic compositions that return significantly overestimated pressures are marked

1059 (Berndt et al. 2001).

1060

1061 Figure 4 Tests performed on the new Jd-in-clinopyroxene barometer using the same test dataset of 1062 experiments performed on $\mathrm{H}_{2} \mathrm{O}$-poor tholeiites plotted in Figure 1. The barometer's abilities to reproduce 1063 experimental pressures with (a) imposed temperatures and (b) iteratively calculated temperatures are 1064 shown, alongside (c) its ability to reproduce experimental temperatures with equation 33 from Putirka 1065 (2008) during iterative calculations. The performance of the new barometer is directly compared with that 1066 of model P1 from Putirka et al. (1996) in (d).

1068 Figure 5 A summary of the clinopyroxene compositions used to investigate magma storage pressures 1069 under Icelandic rift zones. Clinopyroxene compositions and components were calculated on a six oxygen 1070 (6O) basis following the methods outlined in Table 3 from Putirka (2008). Horizontal black bars on (c) 1071 and (d) show the lower limits of $\mathrm{Al}(6 \mathrm{O})$ and $\mathrm{Jd}$ considered to represent equilibrium sector zone 1072 compositions and reliable analyses respectively. See the main text for further discussion. Unzoned 1073 experimental clinopyroxene compositions from Husen et al. (2016) are also shown to aid in the 1074 identification of equilibrium sector zone compositions. Low- and high-Al sector zone arrays are also 1075 marked on (c).

1076

1077 Figure 6 Kernel density estimates (KDEs) of clinopyroxene Mg\# distributions for (a) the full 1078 clinopyroxene compilation and (b) clinopyroxene compositions to which equilibrium liquid compositions 1079 were successfully matched. KDEs were calculated with a bandwidth comparable to the $1 \sigma$ precision of 
Mg\# determinations $( \pm 0.5 \mathrm{~mol} . \%)$. Vertical red lines show the $\mathrm{Mg} \#$ of clinopyroxenes calculated to be in

1081 equilibrium with erupted liquids (see the main text for details). Only whole-rock analyses of groundmass

1082 separates, which are an inexact reflection of liquid compositions, were available for the Thjórsá lava

1083 (Halldórsson et al. 2008), so a tentative equilibrium clinopyroxene composition is marked with a vertical

1084 dashed line. Distinct clinopyroxene populations from the Laki and Thjórsá lavas, and the 10 ka Grímsvötn

1085 tephra series are marked with different colors in (b). KDEs of the full clinopyroxene compilation are also

1086 shown in pale grey behind the KDEs of matched clinopyroxenes. Matches were found for most

1087 clinopyroxene compositions, with the notable exception of the most primitive clinopyroxenes from

1088 Borgarhraun $\left(\mathrm{Mg} \#_{\mathrm{cpx}}>90\right)$, which grew from melts that were much more primitive than any known to

1089 have erupted in Iceland (Winpenny and Maclennan 2011)

Figure 7 A summary of the clinopyroxene compositions to which equilibrium liquid compositions were successfully matched. Symbols as in Figure 5.

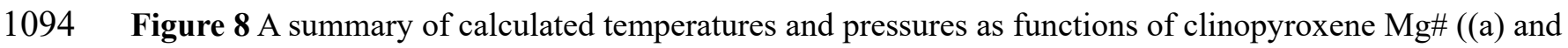

Figure 9 KDEs of pressures and temperatures calculated for the clinopyroxene populations identified in

1099 Figure 6b. (a) Pressure KDEs calculated with a bandwidth of $1.4 \mathrm{kbar}$, which is comparable to the SEE of

1100 the new Jd-in-clinopyroxene barometer (Figure 2b). (b) Temperature KDEs calculated with a bandwidth

1101 of $17{ }^{\circ} \mathrm{C}$, which is comparable with the SEE of equation 33 from Putirka (2008) when applied to

1102 experiments on low- $\mathrm{H}_{2} \mathrm{O}$ tholeiites in conjunction with the new barometer (Figure $4 \mathrm{c}$ ).

1104 Supplementary Figure 1 A comparison of pressures returned from iterative thermobarometric 1105 calculations performed on Icelandic clinopyroxene compositions using our new barometer and equation 
110633 from Putirka (2008), and expressions from Putirka et al. (1996). A one-to-one line and a regression 1107 through the calculation results are shown in grey and black respectively. 


\section{TABLES}

1109 Table 1 A summary of the experimental data used to calibrate the new Jd-in-clinopyroxene barometer Source $\quad n \quad$ Pressure (kbar) Temperature $\left({ }^{\circ} \mathrm{C}\right) \quad \mathrm{H}_{2} \mathrm{O}($ wt.\%)

Blatter and Carmichael (2001) $\quad 13 \quad 0.548-2.28 \quad 930-1000 \quad 3-6$

Kinzler and Grove (1992) $\quad 30 \quad 9-16 \quad 1250-1350 \quad$ anhydrous

Moore and Carmichael (1998) $\quad 10 \quad 0.441-2.496 \quad 950-1075 \quad 3-5$

Putirka et al. (1996) $\quad 23 \quad 8-20 \quad 1100-1390 \quad$ anhydrous

Sisson and Grove (1993) $\quad 17 \quad 1-2 \quad 965-1082 \quad 3.8-6.2$

Yang et al. (1996) $\quad 20 \quad 0.001 \quad 1110-1190 \quad$ anhydrous

1110

1111 Table 2 Icelandic clinopyroxene data sources

Eruption Sources

Holuhraun 1 and $2 \quad$ Hartley and Thordarson (2013)

Laki Neave et al. (2013)

10 ka Grímsvötn tephra series Neave et al. (2015)

Skuggafjöll Neave et al. (2014)

Thjórsá Passmore (2009)

Borgarhraun Maclennan et al. (2001), Maclennan et al. (2003a)

and Slater et al. (2001)

1113 Table 3 Barometric results and properties of Gaussian fits to pressures calculated for individual

1114 clinopyroxene populations

\begin{tabular}{llllll} 
Clinopyroxene population & Mean & $1 \sigma$ & $1 \mathrm{SEE}$ & Mean $_{\text {Gaussian }}$ & $1 \sigma_{\text {Gaussian }}$ \\
\hline Holuhraun 1 and 2 & 2.4 & 0.9 & 0.3 & 2.4 & 1.7 \\
Laki, $\mathrm{Mg} \#_{\mathrm{cpx}}>80$ & 3.8 & 0.6 & 0.1 & 3.7 & 1.5 \\
Laki, $\mathrm{Mg} \#_{\mathrm{cpx}}<80$ & 2.7 & 1.0 & 0.2 & 2.8 & 1.6 \\
Grímsvötn tephra series, $\mathrm{Mg} \#_{\mathrm{cpx}}>80$ & 3.5 & 1.0 & 0.4 & 3.5 & 1.6 \\
Grímsvötn tephra series, $\mathrm{Mg} \#_{\mathrm{cpx}}<80$ & 2.9 & 0.9 & 0.2 & 2.8 & 1.6 \\
Skuggafjöll & 3.6 & 1.3 & 0.1 & 3.6 & 1.8 \\
Thjórsá, $\mathrm{Mg} \#_{\mathrm{cpx}}>80$ & 3.7 & 1.3 & 0.4 & 3.6 & 1.7 \\
Thjórsá, $\mathrm{Mg} \#_{\mathrm{cpx}}<80$ & 2.6 & 1.2 & 0.3 & 2.5 & 1.8 \\
Borgarhraun & 4.8 & 1.4 & 0.1 & 4.8 & 1.8
\end{tabular}


Figure 1
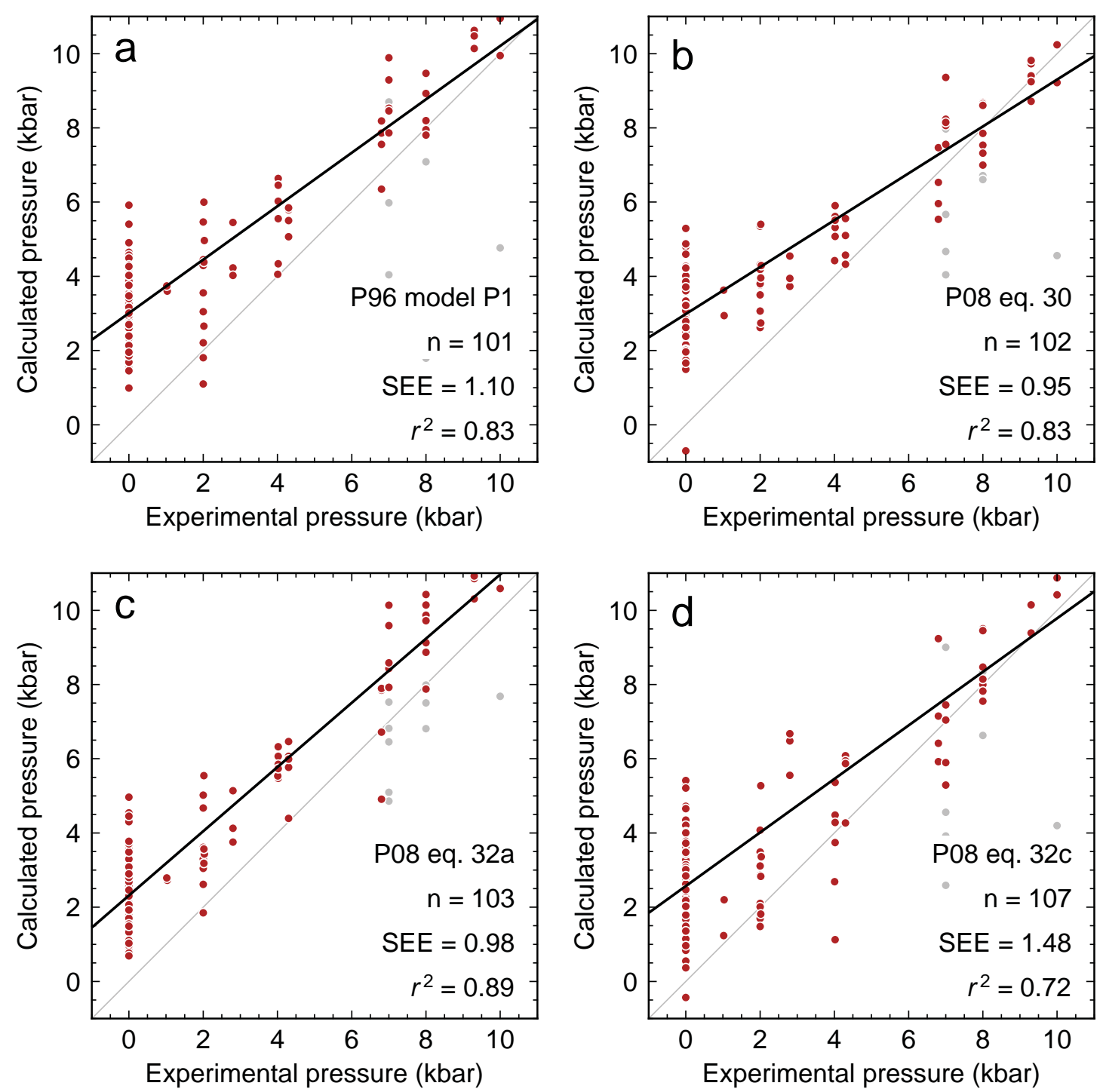
Figure 2
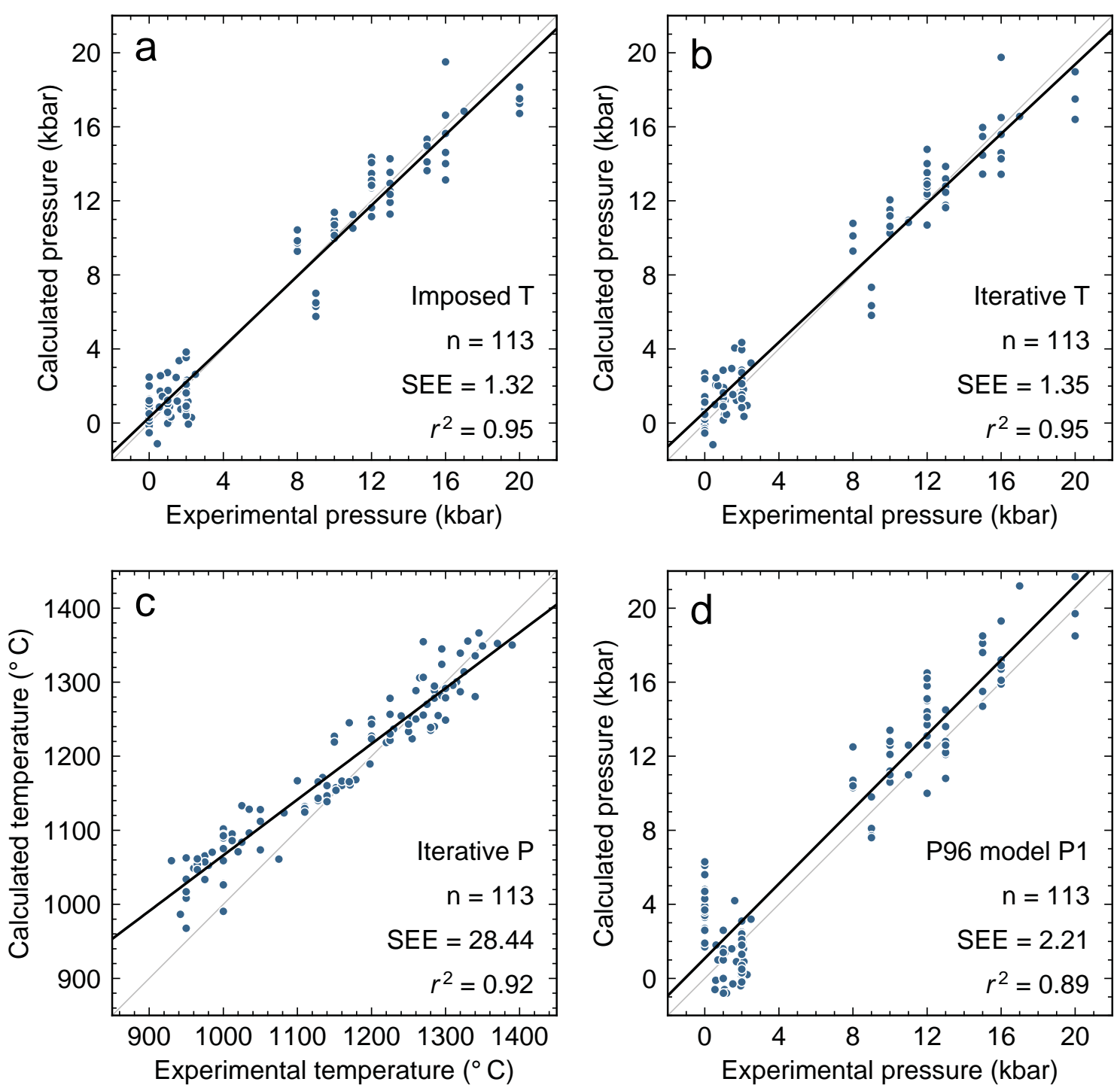
Figure 3
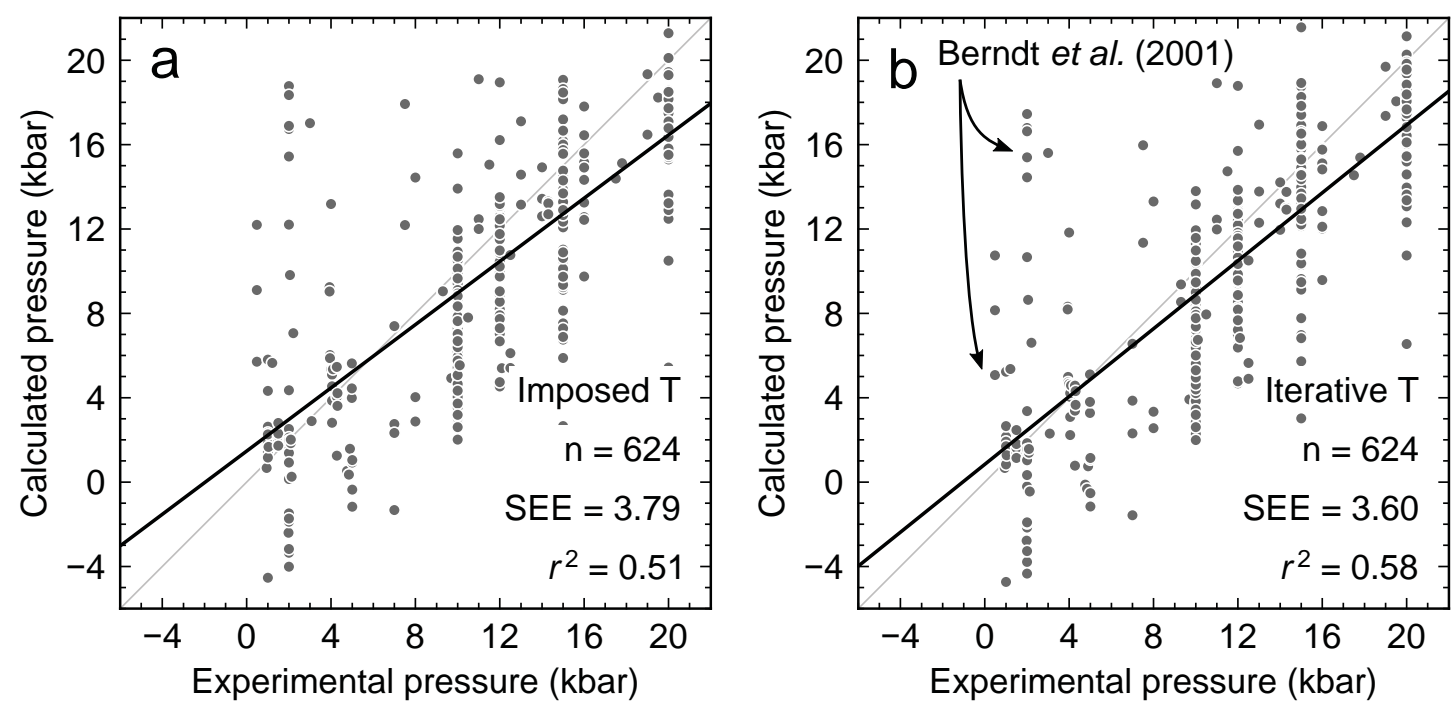
Figure 4
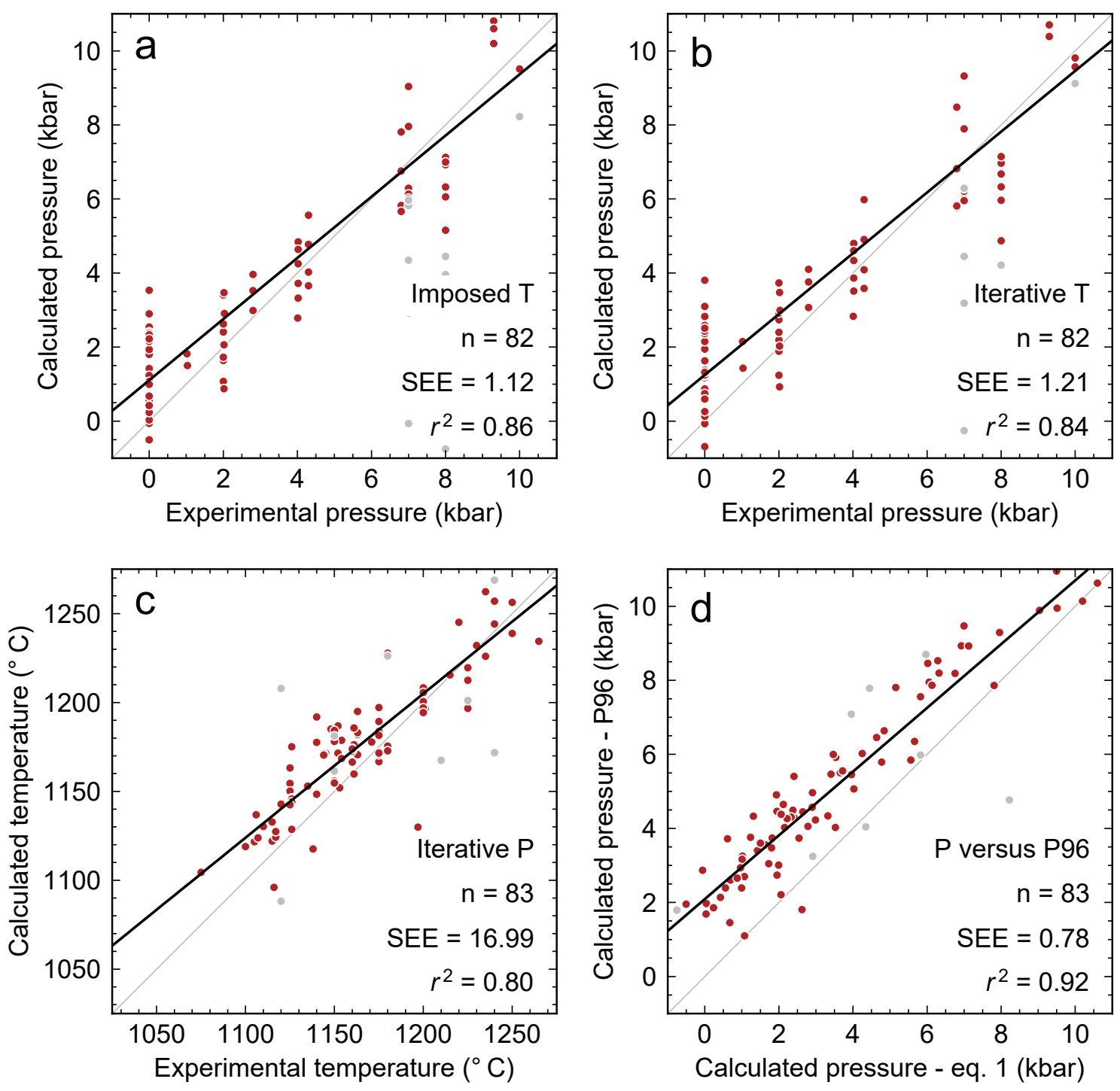


\section{Figure 5}
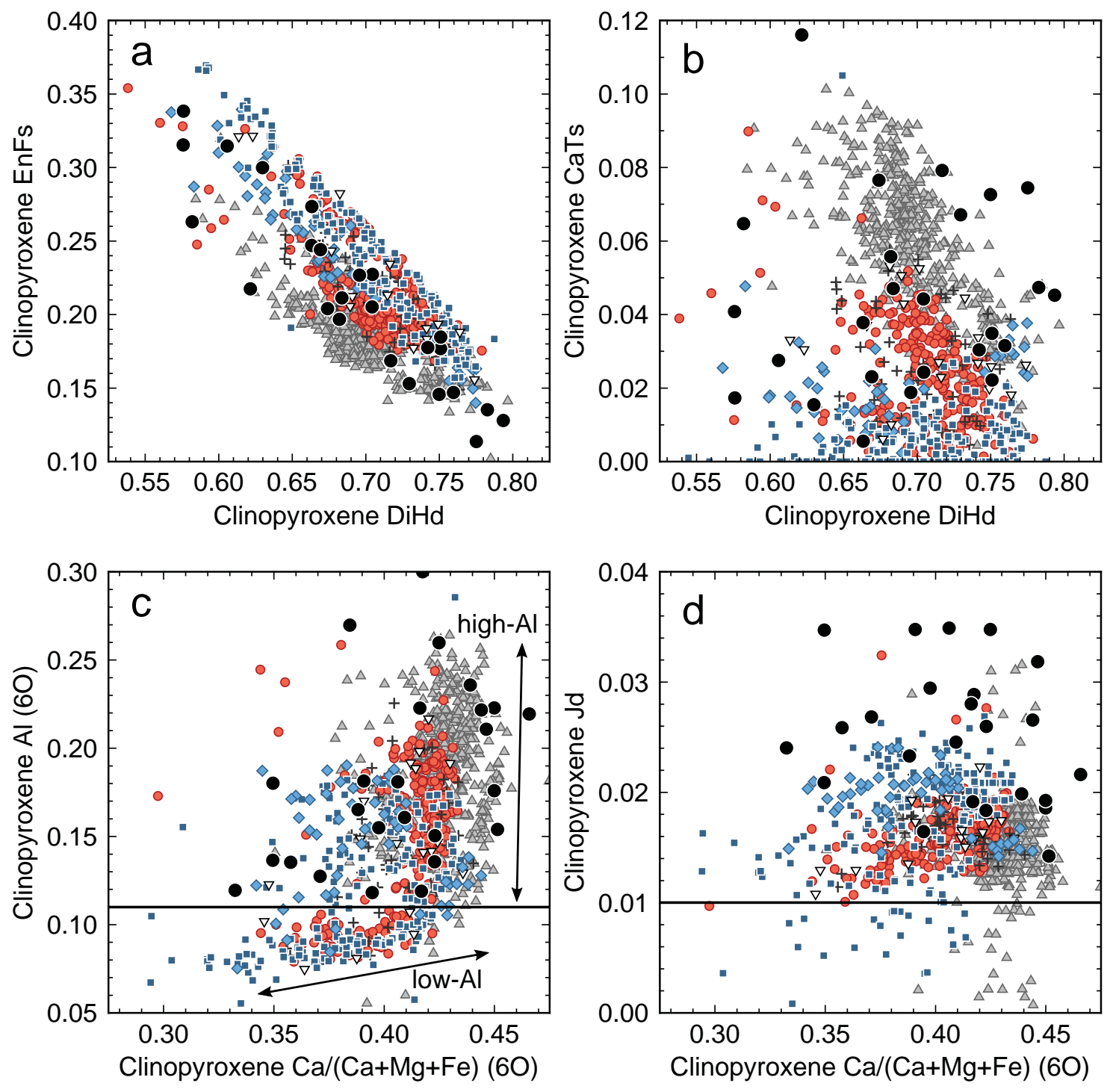

$\nabla$ Holuhraun 1 and 2 " Laki

$\diamond 10$ ka Grímsvötn • Skuggafjöll

+ Thjórsá $\quad \Delta$ Borgarhraun

- Experimental (Husen et al., 2016) 


\section{Figure 6}
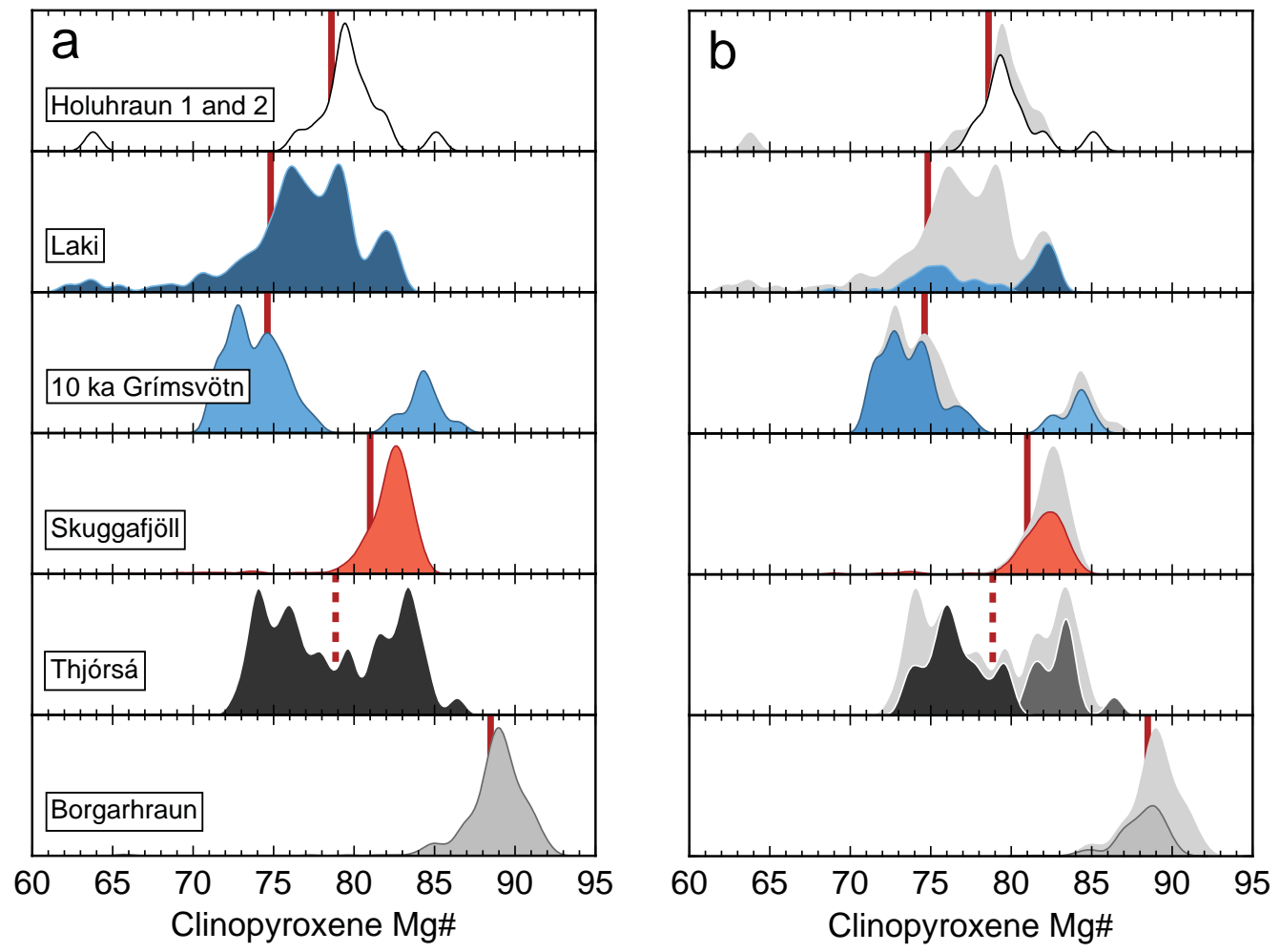


\section{Figure 7}
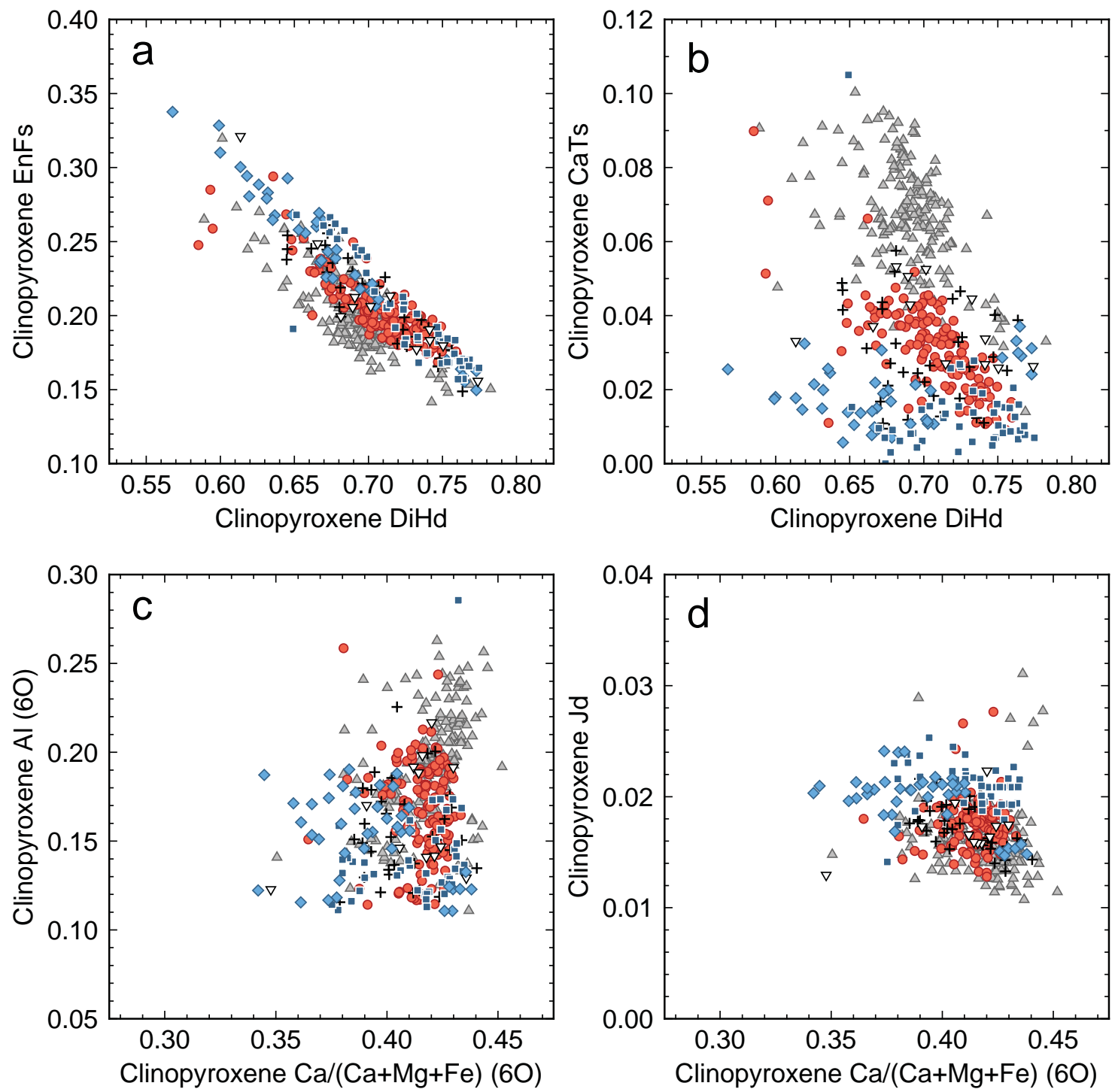

$$
\begin{aligned}
& \nabla \text { Holuhraun } 1 \text { and } 2 \text { "Laki } \\
& \text { - } 10 \text { ka Grímsvötn • Skuggafjöll } \\
& \text { + Thjórsá } \quad \Delta \text { Borgarhraun }
\end{aligned}
$$




\section{Figure 8}
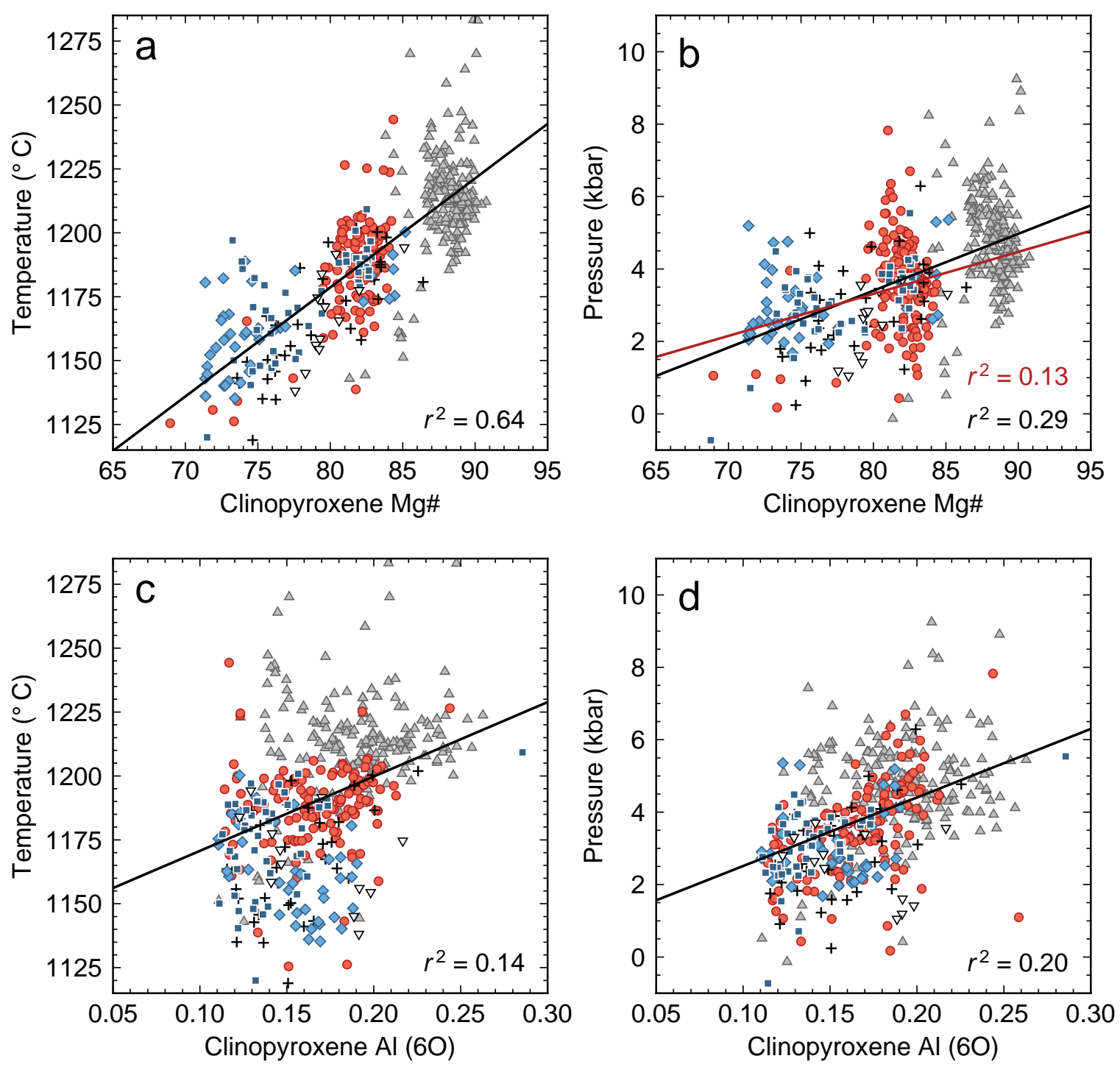

$\nabla$ Holuhraun 1 and 2 - Laki

$\diamond 10$ ka Grímsvötn

+ Thjórsá 


\section{Figure 9}
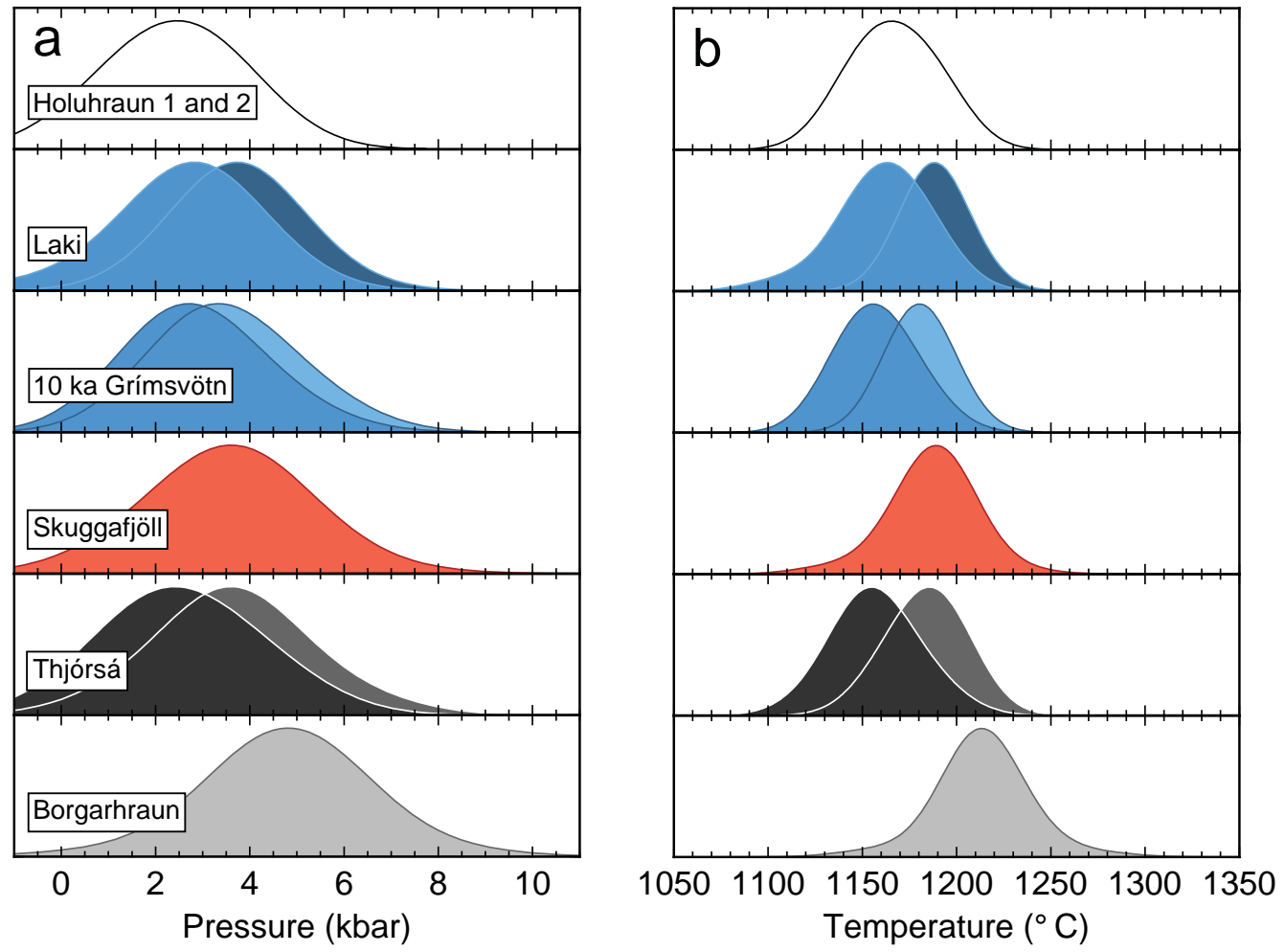